\title{
Indirect bronchial hyperresponsiveness in asthma: mechanisms, pharmacology and implications for clinical research
}

\author{
J. Van Schoor, G.F. Joos, R.A. Pauwels
}

\begin{abstract}
Indirect bronchial hyperresponsiveness in asthma: mechanisms, pharmacology and implications for clinical research. J. Van Schoor, G.F. Joos, R.A. Pauwels. (C)ERS Journals Ltd 2000.

ABSTRACT: Bronchial hyperresponsiveness (BHR), an abnormal increase in airflow limitation following the exposure to a stimulus, is an important pathophysiological characteristic of bronchial asthma. Because of heterogeneity of the airway response to different stimuli, the latter have been divided into direct and indirect stimuli. Direct stimuli cause airflow limitation by a direct action on the effector cells involved in the airflow limitation, while indirect stimuli exert their action essentially on inflammatory and neuronal cells that act as an intermediary between the stimulus and the effector cells.

This manuscript reviews the clinical and experimental studies on the mechanisms involved in indirect BHR in patients with asthma. Pharmacological stimuli (adenosine, tachykinins, bradykinin, sodium metabisulphite/sulphur dioxide, and propranolol) as well as physical stimuli (exercise, nonisotonic aerosols, and isocapnic hyperventilation) are discussed.

The results of the different direct and indirect bronchial challenge tests are only weakly correlated and are therefore not mutually interchangeable. Limited available data (studies on the effects of allergen avoidance and inhaled corticosteroids) suggest that indirectly acting bronchial stimuli (especially adenosine) might better reflect the degree of airway inflammation than directly acting stimuli. It remains to be established whether monitoring of indirect BHR as a surrogate marker of inflammation (in addition to symptoms and lung function) is of clinical relevance to the long-term management of asthmatic patients. This seems to be the case for the direct stimulus methacholine. More work needs to be performed to find out whether, indirect stimuli are more suitable in asthma monitoring than direct ones. Recommendations on the application of indirect challenges in clinical practice and research will shortly be available from the European Respiratory Society Task Force.

Eur Respir J 2000; 16: 514-533.
\end{abstract}

Bronchial hyperresponsiveness (BHR) is an important pathophysiological characteristic of bronchial asthma that can explain many of its clinical features. Bronchial or airway hyperresponsiveness is an abnormal increase in airflow limitation following the exposure to a stimulus. The word "abnormal" refers to a comparison with the airway response to the same agonist, using the same method to measure the airflow limitation, in a group of healthy subjects. The wording "airflow limitation" is chosen because it encompasses the different mechanisms that can lead to a decrease in the parameters of airflow [1].

In order to highlight the heterogeneity of the airway response to the different stimuli and to better understand the effect of treatment on BHR, the stimuli have been divided into direct and indirect [2-4]. Direct stimuli cause airflow limitation by a direct action on the effector cells involved in the airflow limitation, such as airway smooth muscle cells, bronchial vascular endothelial cells and mucus producing cells. Indirect stimuli cause airflow limitation by an action on cells other than the effector cells; these cells then interact in a second time with these effector cells (fig. 1). Cells that act as an intermediary
Dept of Respiratory Diseases, Ghent University Hospital, Ghent, Belgium.

Correspondence: G. Joos

Dept of Respiratory Diseases

$7 \mathrm{~K} 12 \mathrm{IE}$

University Hospital

De Pintelaan 185

B-9000 Ghent

Belgium.

Fax: 3292402341

Keywords: Adenosine challenge

airway inflammation

asthma

bronchial challenges

bronchial hyperresponsiveness

exercise challenge

Received: June 231999

Accepted after revision April 282000 between the indirect stimuli and the effector cells are inflammatory cells (such as mast cells) and neuronal cells. The stimuli themselves have been classified according to the dominant mechanism of airflow limitation in response to the stimulus (table 1); some stimuli have both a direct and an indirect activity (fig. 2).

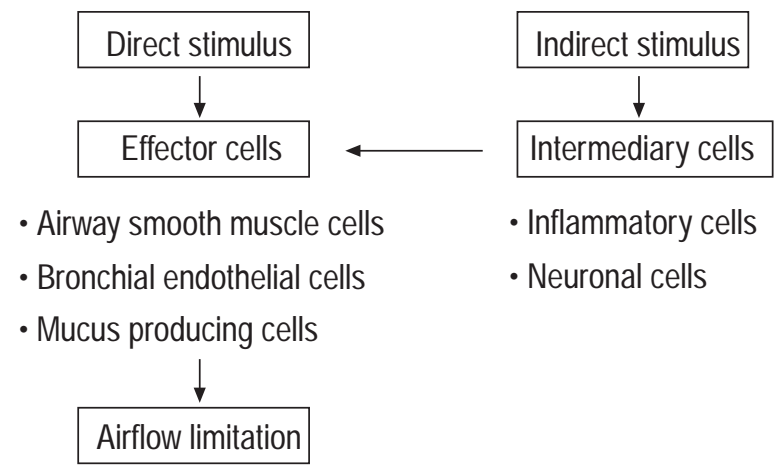

Fig. 1. - Mechanisms via which directly and indirectly acting stimuli cause airflow limitation. 
Table 1. - Stimuli to measure bronchial responsiveness

\begin{tabular}{ll}
\hline Direct stimuli & Indirect stimuli \\
\hline Acetylcholine & Adenosine \\
Methacholine & Tachykinins (SP, NKA) \\
Carbachol & Bradykinin \\
Histamine & Metabisulphite $/ \mathrm{SO}_{2}$ \\
Prostaglandin $\mathrm{D}_{2}$ & Propranolol \\
Leukotriene $\mathrm{C}_{4} / \mathrm{D}_{4} / \mathrm{E}_{4}$ & Exercise \\
& Hyper/hypotonic aerosols \\
& Isocapnic hyperventilation \\
\hline
\end{tabular}

SP: substance P; NKA: neurokinin A.

The aim of the present manuscript is to review the clinical and experimental studies, dissecting the mechanisms involved in indirect BHR; the discussion centres around data obtained in patients with asthma. When such data are not currently available, results obtained from animal models or from experiments on isolated human bronchi are included. There are important variations in the methodology of the different provocations; fortunately, there is an increasing awareness concerning the importance of this issue, and attempts towards greater standardization between different centres have resulted in the publication of guidelines $[4,5]$. Increasingly these indirect challenges are considered to provide additional information in the diagnosis and monitoring of asthma in children and adults. They are increasingly used in studies to assess the antiasthmatic effect of an intervention. Currently an European Respiratory Society (ERS) Task Force on "Indirect challenges" is working on a summary report with recommendations.

\section{Pharmacological stimuli}

\section{Adenosine 5'-monophosphate}

Adenosine (9- $\beta$-D-ribofuranosyl-6-aminopurine) is a naturally occurring nucleoside that serves an autocoid function in a large number of physiological systems, and may be considered as a secondary product of the inflammatory response. Most adenosine is derived from cleavage of the nucleotide adenosine 5'-monophosphate (AMP). AMP re-

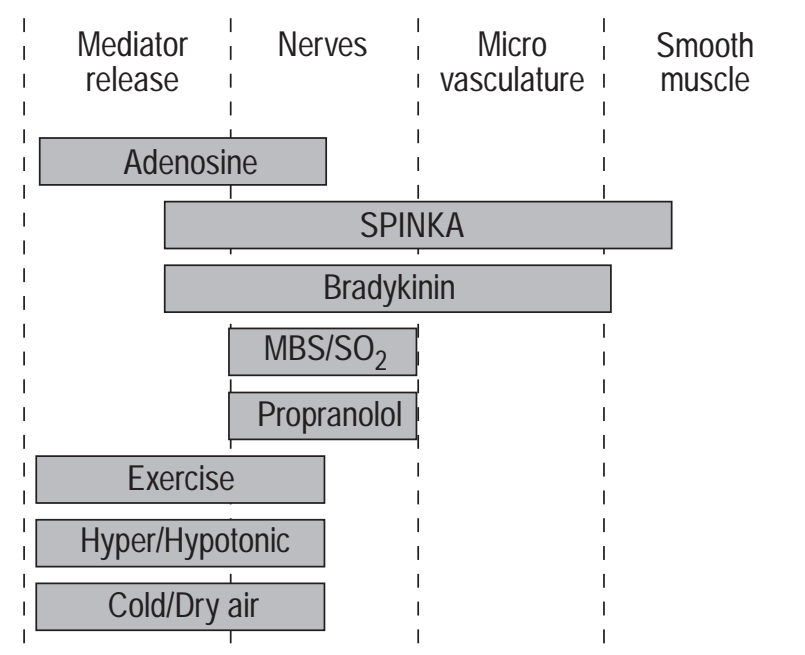

Fig. 2. - Heterogeneous mechanisms of indirect airway hyperresponsiveness in asthma. MBS: sodium metabisulphite; $\mathrm{SO}_{2}$ : sulphur dioxide. leased from cells undergoes hydrolysis by the ubiquitous ectoenzyme 5'-nucleotidase (EC 3.1.3.5), which is principally associated with the cell plasma membrane, to produce adenosine that may be either salvaged to produce new AMP after re-uptake in the cell or degraded to its end product uric acid, which is excreted via the urine [6].

Adenosine exerts its effects on human cells through interaction with specific adenosine (P1) receptors, of which four subtypes $\left(A_{1}, A_{2 A}, A_{2 B}\right.$, and $\left.A_{3}\right)$ have been described [7]. Our knowledge on the adenosine receptors mediating adenosine-induced airflow limitation is rather limited at present. The $A_{1}, A_{2 B}$, and $A_{3}$ receptors have been shown to be involved in various animal and human models, but the development of specific and potent adenosine receptor agonists and antagonists for use in vivo in asthma must be awaited to further elucidate the relative importance of these receptors [8]. In particular, the potential role of $A_{2 B}$ receptors is being increasingly recognized [9].

Inhalation of adenosine was shown to have no detectable effect on airway calibre in normal subjects, but elicited a concentration-dependent airflow limitation in patients with both allergic and nonallergic asthma [10], and in atopic, nonasthmatic subjects [11]. Responsiveness to adenosine is greater in atopic asthmatics than in atopic normal subjects, without a sharp cut-off between the groups [12]. Repeated inhalation of AMP by atopic nonasthmatics induces airway refractoriness through mechanisms likely to involve depletion of mast cell mediators or downregulation of purinoreceptors. The refractory period lasts $\sim 4 \mathrm{~h}$ [13]. The airway responsiveness to AMP increases after inhalation of hypertonic saline [14]. Adenosine 5'-monophosphate (maximal concentration: 1.08 $\mathrm{M})$ is much more hydrosoluble than adenosine itself (maximal concentration: $25 \mathrm{mM}$ ) and is therefore preferred for inhalation challenges [12].

In vitro studies clearly indicated that mast cell derived mediators are involved in the adenosine response. Adenosine potentiates histamine release from human lung mast cells after anti-immunoglobulin (Ig)E challenge through $\mathrm{A}_{2}$ receptor stimulation [15]; similarly, adenosine potentiates the release of both preformed (histamine) and newly formed leukotriene C (LTC4) mediators from immunologically activated human lung mast cells, most probably via an $\mathrm{A}_{2}$-mediated mechanism [16]. In addition, mast cell derived mediators (prostaglandin $\mathrm{D}_{2}\left(\mathrm{PGD}_{2}\right)$, histamine, and tryptase) were found to be markedly increased in bronchoalveolar lavage fluid, obtained immediately after endobronchial AMP instillation in asthmatics [17]. Finally, plasma histamine increased significantly following AMP challenge in atopic nonasthmatics [11], while serum neutrophil chemotactic factor showed a significant elevation in asthmatics, but not in normal subjects following adenosine bronchoprovocation [18].

In vitro studies on isolated human airways confirmed that bronchi from asthmatics are more sensitive to adenosine than are bronchi from nonasthmatics. The contractile effect of adenosine was inhibited by nonselective $A_{1}$ and dual $A_{1} / A_{2}$ receptor antagonists. In addition, the contractile response to adenosine was reduced by either antihistamines or drugs that inhibited the action or formation of leukotrienes. Moreover, when these two classes of drugs were combined, the response to adenosine was abolished [19]. These findings are in agreement with the observation in clinical studies that oral pretreatment with $180 \mathrm{mg}$ 
Table 2. - Inhibitory effects of drugs on the airflow limitation, induced by indirectly acting pharmacological stimuli in asthma

\begin{tabular}{|c|c|c|c|c|c|}
\hline & Adenosine & $\mathrm{SP} / \mathrm{NKA}$ & Bradykinin & $\mathrm{MBS} / \mathrm{SO}_{2}$ & Propranolol \\
\hline $\mathrm{H}_{1}$-antagonists & +++ & - & + & - & $+/-$ \\
\hline 5-LO-I/Cys $\mathrm{LT}_{1}$ antagonists/FLAP-I & ++ & ND & ND & + & - \\
\hline COX-I & + & + & + & + & ND \\
\hline Anticholinergics & + & + & ++ & $-/++(*)$ & +++ \\
\hline TK-antagonists & ND & + & $-/+$ & $\mathrm{ND}$ & ND \\
\hline SCG/NED & +++ & ++ & ++ & ++ & $-/+$ \\
\hline NOS-inhibitors & $?$ & ND & + & - & ND \\
\hline Furosemide & ++ & + & ++ & ++ & + \\
\hline Heparin & + & ND & ND & - & ND \\
\hline iGCS & ++ & + & $-/+$ & $-/+$ & - \\
\hline
\end{tabular}

SP: substance P; NKA: neurokinin A; MBS: metabisulphite; $\mathrm{SO}_{2}$ : sulphur dioxide; FLAP-I: 5-lipoxygenase activating protein inhibitor; COX-I: cyclooxygenase-inhibitor; TK: tachykinins; SCG: sodium cromoglycate; NED: nedocromil sodium; NOS: nitric oxide synthase; iGCS: inhaled glucocorticosteroids; *: wide interindividual variations; ND: no data available; ?: inconclusive data; +: inhibitory effect; -: no inhibitory effect.

of the $\mathrm{H} 1$ receptor antagonist terfenadine had a major inhibitory effect on the airway response to AMP in atopic [20] and nonatopic asthma [21] (table 2). The confirmation of a leukotriene component in the AMP-induced airflow limitation in asthma was obtained in a subsequent clinical study, where it was shown that oral pretreatment with $200 \mathrm{mg}$ of ABT-761 (atreleuton), a 5-lipoxygenase inhibitor, reduced the area under the FEV1-time curve by $>80 \%$ [22]. The results from studies with cyclo-oxygenase inhibitors show that the newly formed prostanoids also play an, albeit modest, role in the AMP-induced airflow limitation [23-26].

Enhancement of mast cell mediator release, although prominent, is not the only mechanism accounting for the airflow limitation by inhaled adenosine. Pretreating asthmatics with $500 \mu \mathrm{g}$ of the nebulized anticholinergic ipratropium bromide resulted in a protective 2.5 -fold shift of provocative concentration of the drug causing a $20 \%$ fall in forced expiratory volume in one second (PC20) [27]. Similarly, inhalation of $40 \mu \mathrm{g}$ of ipratropium bromide via pMDI in asthmatics afforded a 2.2-fold protective shift of provocative dose of the drug causing a $20 \%$ fall in forced expiratory volume in one second (PD20) AMP [28]. These findings suggest that cholinergic, vagal pathways contribute a small, but significant component of the airflow limitation induced by inhaled AMP in asthma. Pretreatment with the inhaled neutral endopeptidase (NEP) inhibitor phosphoramidon did not have an effect on AMP-induced BHR; this suggests that stimulation of airway nerves with local release of tachykinins does not play an important role in the airway response to adenosine [29].

Inhaled SCG and nedocromil sodium (NED) are highly effective in attenuating the airway response to adenosine and AMP challenge in atopic nonasthmatics [30], atopic asthmatics [31, 32], and nonatopic asthmatics [32]. The exact mechanism of action of these molecules is not fully understood; it is suggested that their actions, such as the prevention of release of mediators from mast cells or eosinophils, or the inhibition of firing of sensory nerve fibres, are the result of their blocking activity on chloride channels [33].

It is not clear whether inhalation of adenosine activates the nitric oxide (NO) synthase pathway. In a trial on the effect of inhaled $\mathrm{N}$-nitro-L-arginine methyl ester (L-NA$\mathrm{ME}$ ), a NO synthase inhibitor, a small (approximately one doubling dose) increase in airway responsiveness to both histamine and adenosine was noted [34].

Inhalation of furosemide protects asthmatic airways against AMP-induced airflow limitation [35, 36]. The exact mechanism through which furosemide conveys its protective effects is not known; more than one mechanism may be involved. The fact that furosemide is more potent in protecting against indirect (e.g. AMP) when compared to direct (e.g. methacholine) bronchoconstrictor stimuli [35], however, suggests an additional inhibitory effect on mediator release from mast cells and/or inhibition of neural pathways. Furthermore, inhaled heparin resulted in a 2.4-fold protection against AMP in atopic asthmatics; it is believed that the bronchoprotective action of heparin is also related to an inhibitory modulation of mast cell activation [37]; this finding, however, was not confirmed in another study with a different interval between heparin inhalation and AMP challenge [38].

Finally, the effect of inhaled glucocorticosteroids (iGCS) on AMP challenge has been tested. Treatment with inhaled budesonide ( $800 \mu \mathrm{g}$ b.d.) for 14 days was found to have a significantly greater effect on airway responsiveness to AMP when compared to the effects seen on the airway responsiveness to methacholine and sodium metabisulphite in atopic asthmatics. The rightward shifts in the dose-response curves were 2.9, 1.2 and 1.1 doubling dilutions, respectively [39]. One and two months treatment with inhaled beclomethasone diproprionate (400 $\mu \mathrm{g}$. day $^{-1}$ ) significantly increased the PD20 for AMP, but not for bradykinin or methacholine, in children with recurrent wheeze, suggesting that AMP responsiveness may be a superior marker to predict response to inhaled steroid treatment [40]. The most likely explanation for this action of iGCS is a reduction of airway mast cell numbers and/or function [40].

In summary, although there are no selective adenosine receptor antagonists available for use in humans to date, alternative pharmacological approaches have suggested that adenosine acts indirectly through activation of specific receptors on intermediary inflammatory cells such as mast cells and possibly on afferent nerve endings. Adenosine is not merely one of a series of scientifically interesting pharmacological stimuli that cause airflow limitation in asthma, but may also be a mediator involved in asthma. AMPinduced airflow limitation may well depend on the state of airway mast cell priming and a bronchoprovocation with 
AMP might therefore be useful as an in vivo test for this. Recent clinical studies suggest that AMP bronchoprovocation is a potentially useful marker of disease activity with a closer relationship to the underlying inflammatory process in asthma than is the case for histamine or methacholine $[41,42]$ and as such may have an application in differentiating asthma from other airway diseases and might provide an index that could be used to survey disease progression, monitor treatment, and assess prognosis [43].

\section{Tachykinins}

The neuropeptides, substance $\mathrm{P}(\mathrm{SP})$ and neurokinin $\mathrm{A}$ (NKA) belong to the tachykinin (TK) family of peptides. They are localized to unmyelinated sensory nerves (Cfibres) in human lower airways. Release of TK from Cfibres occurs in response to a variety of stimuli, e.g. exposure to allergen, ozone or inflammatory mediators $[44,45]$. Findings from animal and human work suggest that non-neural cells (endothelial cells, eosinophils, macrophages, dendritic cells) can also be a source of TKs and that immune stimuli can boost TK production and secretion from immunocytes [46, 47]. SP and NKA have potent effects on bronchomotor tone (constriction of bronchial smooth muscle), airway secretions (stimulation of mucus secretion from submucosal glands), bronchial circulation (vasodilatation and microvascular leakage), and on inflammatory and immune cells (pro-inflammatory effects) [44]. The airway effects of the TKs are mediated via tachykinin $\mathrm{NK}_{1}$ and $\mathrm{NK}_{2}$ receptors; there is no evidence for the presence of $\mathrm{NK}_{3}$ receptors in the human airways. SP has the greatest affinity for the $\mathrm{NK}_{1}$ receptor ("SP-preferring"), while NKA has the greatest affinity for the $\mathrm{NK}_{2}$ receptor ("NKA-preferring"), but there is some cross-reactivity [48]. Tachykinins constrict smooth muscle of human airways in vitro via $\mathrm{NK}_{2}$ receptors [49-51]; in addition, it has been shown that stimulation of $\mathrm{NK}_{1}$ receptors on small bronchi induced contraction [52].

Following their release, the TKs are degraded by at least two enzymes: neutral endopeptidase (NEP; EC 3.4.24.11) [53] and angiotensin converting enzyme (ACE; EC 3.4.15.1). NEP is widely distributed on a variety of airway cells, but especially on the airway epithelium; it appears to be the most important enzyme for the breakdown of TK in tissues. ACE, on the other hand, is localized predominantly to the vascular endothelium and therefore breaks down intravascular peptides [54].

Tachykinins are potent constrictors of airways. NKA and SP induce bronchoconstriction in humans, with asthmatics being more sensitive than normal subjects [55-58]. In a study of children SP-induced bronchoconstriction increased with severity of asthma [59].

The bronchoconstrictor effect of inhaled TKs is modulated by neutral endopeptidase (NEP). Pretreatment with the NEP-inhibitors thiorphan or phosphoramidon enhanced the airflow limitation to inhaled NKA in both normal and asthmatic subjects $[57,58,60]$. A reduction of NEP activity in asthma could not be confirmed, as enhancement of NKA-induced airflow limitation following inhalation of thiorphan was of a similar magnitude in patients with mild asthma compared to nonasthmatic subjects [41].
It has not yet been possible to clearly establish which type of TK receptor is most important in mediating airflow limitation in asthmatic patients. In vitro studies on isolated human bronchi have shown that $\mathrm{NK}_{2}$ receptors are present on smooth muscle of both large and small airways and mediate part of the bronchoconstrictor effect of tachykinins. $\mathrm{NK}_{1}$ receptors are localized on smooth muscle of small airways and are responsible for a transient, lowintensity contraction mediated by prostanoids [52]. Inhaled FK224 (4 mg), a mixed $\mathrm{NK}_{1} / \mathrm{NK}_{2}$ receptor antagonist of low potency, offered no protection against NKA-induced airflow limitation [61], while the potent nonpeptide $\mathrm{NK}_{2}$ antagonist SR48968 (saredutant) (100 mg orally) provided a small, but consistent protection against NKA challenge [62]. As the number of potent and specific nonpeptide TK receptor antagonists suitable for use in humans is now increasing rapidly, more information should become available in the years to come.

A lot of pharmacological work has already been carried out to determine the mechanisms involved in the TKinduced airflow limitation. Pretreatment with $\mathrm{H}_{1}$-receptor antagonists does not affect bronchoconstriction, induced by sensory neuropeptides. Oral astemizole $(20 \mathrm{mg} b . d$. for three days) did not reduce SP-induced airflow limitation [63], and oral terfenadine $\left(180 \mathrm{mg} \cdot \mathrm{day}^{-1}\right.$ for three days) had no effect on NKA-induced airflow limitation [64]. This is in keeping with the finding that SP (1-10 $\mu \mathrm{M})$ does not release histamine from human lung mast cells from nonasthmatics, obtained from lung tissue [65]. Other authors, however, demonstrated that higher concentrations of SP $(50 \mu \mathrm{M})$ were able to induce histamine release from human lung mast cells from nonasthmatics, obtained at bronchoalveolar lavage (BAL) [66]. Pretreatment with inhaled lysine-acetylsalicylate (L-ASA, 90 $\mathrm{mg} \cdot \mathrm{mL}^{-1}$ ) elicited a small but significant protection against NKA-induced airflow limitation; L-ASA failed to show a significant change in airway responsiveness to methacholine. These results suggest that contractile prostaglandins mediate a component of the NKA response in human asthma; their contribution to the overall response, however, is likely to be small [67].

Several authors investigated the possible role of acetylcholine release by post-ganglionic vagal nerve endings in tachykinin-induced airflow limitation. Pretreatment with $400 \mu \mathrm{g}$ of the inhaled anticholinergic drug oxitropium bromide in mild asthmatics did not offer a significant protection against bronchoprovocation with NKA [68]. Others were able to demonstrate a small, but statistically significant protective effect on SP-induced airflow limitation following a pretreatment with $40 \mu \mathrm{g}$ of inhaled ipratropium bromide, suggesting a weak cholinergic activation [63].

A single dose of $4 \mathrm{mg}$ of inhaled nedocromil sodium significantly inhibited SP- [56] and NKA-induced [69] airflow limitation in mild asthmatics. Inhalation of $40 \mathrm{mg}$ of nebulized furosemide partially protects against NKAinduced airflow limitation, suggesting a suppressive action on the neurotransmission [70]. A 14-day course of inhaled steroids (fluticasone propionate, 1,000 $\mu \mathrm{g} \cdot \mathrm{day}^{-1}$ ) induced a more pronounced reduction in bronchial responsiveness to NKA as compared to methacholine [71].

In summary, TKs are released not only from sensory nerve endings, but also from various non-neural cells, and they are of potentially greater importance as mediators of 
asthma than previously thought. Performing bronchial challenges with TKs is mainly of pathophysiological importance, in order to elucidate the actions of the different TKs and to study the role of the airway TK receptors. They are currently employed to evaluate newly developed TK receptor antagonists. The high cost of these peptides, however, will probably limit their use to fundamental and clinical research purposes [44].

\section{Bradykinin}

Kinins are naturally occurring vasoactive peptides formed de novo in body fluids and tissues during inflammatory processes. Plasma kallikrein digests high molecular weight kininogen (HMWK) to generate bradykinin, while tissue kallikreins readily release kinins from both HMWK (bradykinin) and low molecular weight kininogen (LMWK) (kallidin). The decapeptide kallidin (lysyl-bradykinin) is rapidly converted to the nonapeptide bradykinin by the enzyme aminopeptidase-M. Once generated, the kinins exert their actions through interaction with specific cell surface bradykinin (B) receptors, named $B_{1}$ and $B_{2}$. The effects of bradykinin on airways are mediated via $\mathrm{B}_{2}$ receptors. Bradykinin is metabolized by several peptidases, the most important of which are carboxypeptidase $\mathrm{N}$ (kininase I), ACE (kininase II), and NEP (see tachykinins) [72].

Inhalation of bradykinin results in a concentration-dependent airflow limitation in patients with asthma. Patients with asthma are hyperresponsive to bradykinin, when compared to normal subjects [73-77]. Similarly, local challenge of the distal airways with increasing concentrations of bradykinin, aerosolized through a wedged bronchoscope, produces a dose-dependent increase in resistance in asthmatic, but not in normal subjects [78]. Bradykinin causes maximal airflow limitation at 3-10 min, with recovery occurring within $60 \mathrm{~min}[76,77]$. In asthmatic subjects, bradykinin and kallidin, but not [des$\left.\mathrm{Arg}^{9}\right]$ bradykinin, produce a concentration-related fall in forced expiratory volume in one second (FEV1) [77]. As bradykinin and kallidin are preferential $\mathrm{B}_{2}$ receptor agonists and $\left[\right.$ des-Arg $\left.{ }^{9}\right]$ bradykinin is a selective $B_{1}$ receptor agonist, this suggests that the bradykinin-induced airflow limitation is $\mathrm{B}_{2}$ receptor mediated [72]. This is in keeping with findings in isolated peripheral airways from nonasthmatic subjects: $B_{2}$, but not $B_{1}$ receptor agonists induce contraction, and the $\mathrm{B}_{2}$ receptor antagonist Hoe 140 , but not the $B_{1}$ receptor antagonist [Leu ${ }^{8}$ des-Arg ${ }^{9}$ ] bradykinin, abolishes the bradykinin-induced bronchoconstriction $[79,80]$.

The NEP inhibitor phosphoramidon was found to discretely increase the sensitivity to bradykinin in isolated airways from nonasthmatics [80]; similarly, inhalation of nebulized phosphoramidon had a small, but significant enhancing effect in asthmatics [81]. The enhancing effect of phosphoramidon on bradykinin-induced airflow limitation may be the result of a direct inhibition of bradykinin metabolism and/or of the inhibition of the metabolism of endogenous tachykinins released by bradykinin.

Repeated inhalation of bradykinin induces tachyphylaxis $[76,82]$ that may persist for up to 3 days [83]. The phenomenon of tachyphylaxis is, however, not observed in all subjects with asthma [84]. Repeated exposure of the airways of atopic asthmatics to bradykinin and hypertonic saline results in the development of cross-refractoriness to hypertonic saline and bradykinin respectively, suggesting a shared mechanism for refractoriness produced by these stimuli [85].

The involvement of histamine in bradykinin-induced airflow limitation appears to be very limited [86]. Extensive research has been performed on the role of cyclooxygenase (COX) products in bradykinin-induced airflow limitation. Indomethacin largely inhibited in vitro the bradykinin-induced release of the prostanoids prostaglandin (PG) $\mathrm{PGE}_{2}, \mathrm{PGI}_{2}$, and thromboxane (TX)A $\mathrm{A}_{2}$ from airways of nonasthmatic subjects [80] as well as the bradykinin-induced contraction of isolated nonasthmatic human airways [79, 80], suggesting the involvement of a COX product. In addition, it was shown that cultured human tracheal smooth muscle cells from nonasthmatics release large quantities of $\mathrm{PGE}_{2}$ in response to bradykinin stimulation. The underlying mechanisms are different for the short-term and long-term responses. Although both are mediated by $B_{2}$ receptors, short-term increases are due to the conversion by existing COX-1 of increased arachidonic acid release to $\mathrm{PGE}_{2}$, whereas the long-term increases are mainly due to the induction of COX-2 [87]. However, involvement of prostaglandins in bradykinin-induced airflow limitation in asthma remains controversial. Indeed, cyclooxygenase inhibitors administered orally are relatively ineffective in preventing bradykinininduced airflow limitation in asthma $[76,86]$. The absence of a significant effect may be explained by the poor bioavailability of orally administered cyclooxygenase inhibitors at the level of the airways. Inhalation of LASA ( $4 \mathrm{~mL}$ at $\left.90 \mathrm{mg} \cdot \mathrm{mL}^{-1}\right)$ was indeed more effective in attenuating bradykinin effects than the orally administered doses [88]. Similarly, the tachyphylaxis to bradykinin is not altered by oral administration of the cyclooxygenase inhibitors aspirin (1g) [76] or flurbiprofen $(150 \mathrm{mg})$ [89], suggesting that this phenomenon is not secondary to increased generation of protective prostanoids, such as $\mathrm{PGE}_{2}$ or $\mathrm{PGI}_{2}$.

The thromboxane prostanoid (TP) receptor antagonist GR32191 (vapiprost) effectively antagonized bradykinininduced responses in isolated human peripheral airways, suggesting that the contractile effects of prostanoids released by bradykinin are mediated through the TP receptor $[80,90]$. Furthermore, the $\mathrm{TXA}_{2}$ synthase inhibitor dazoxiben inhibited the bradykinin-induced contraction, while the $\mathrm{TXA}_{2}$ mimetic U-46619 induced contraction, suggesting that $\mathrm{TXA}_{2}$ itself is involved in $\mathrm{TP}$ receptor stimulation [90]. Despite these results, the oral administration of $50 \mathrm{mg}$ of the TP receptor antagonist BAY u 3405 failed to protect against bradykinin-induced airflow limitation in asthma, while being protective against $\mathrm{PGD}_{2}$-induced airflow limitation [91]. This would suggest that the airflow limitation elicited by bradykinin in asthma is not mediated through TP receptors.

The bronchoconstrictor effect of bradykinin is, at least in part, mediated via cholinergic vagal nerves, since pretreatment with ipratropium bromide significantly reduced airflow limitation in asthmatics [76]. Although bradykinin has been shown to release tachykinins in guinea-pig airways [92-94], conclusive evidence for an involvement of tachykinins in bradykinin-induced bronchoconstriction in man is lacking. The initial observation that inhalation 
of FK-224 (4 mg), a cyclopeptide dual tachykinin $\mathrm{NK}_{1}$ / $\mathrm{NK}_{2}$ receptor antagonist, attenuated inhaled bradykinininduced airflow limitation and cough in asthmatics [95] was not confirmed in a subsequent, similar trial [96], in which inhaled FK-224 (2 mg) was only marginally protective and the magnitude of its effect similar to the spontaneous variability in bradykinin responsiveness over several weeks. Moreover, it was shown that FK224 did not protect against inhaled NKA-induced bronchoconstriction in asthma [61].

Cromolyn sodium and nedocromil sodium protect against bradykinin-induced bronchoconstriction in asthmatics [76, 97]. Given the apparently limited role for mast cell-derived mediators the protective effect of cromolyn sodium against bradykinin-induced airflow limitation may be the result of an action at the level of the neural reflexes [33]. Such an action has been demonstrated in the dog lung in vivo, where SCG suppressed the response of sensory "C" fibre endings to capsaicin [98].

Pretreatment with inhaled $\mathrm{N}^{\mathrm{G}}$-monomethyl-L-arginine (L-NMMA), a nitric oxide (NO) synthase inhibitor, significantly potentiated airflow limitation in response to inhaled bradykinin in asthmatics; this suggests that bradykinin activates the NO synthase pathway, leading to the release of $\mathrm{NO}$, which in turn counteracts the bronchoconstrictor response to bradykinin. Endogenous NO therefore appears to have a bronchoprotective role in airways of asthmatic subjects [99].

High concentrations of furosemide inhibit bradykinininduced contraction of small bronchi of nonasthmatic subjects in vitro. As it also inhibits the TX prostanoid (TP) receptor agonist U-46619-induced contraction in a competitive fashion, the mechanism of the protective effect of furosemide in bradykinin-induced bronchoconstriction in vitro may be explained at least partly by antagonism of TP receptors [100]. Inhaled furosemide (40 mg) has also been shown to provide a 5-fold protection in $\mathrm{PC} 20$ against inhaled bradykinin-induced airflow limitation in asthma [36]. As mentioned above, however, it could not be confirmed that TX prostanoid (TP) receptors are also mediating bradykinin-induced airflow limitation in asthmatic patients [91].

Three weeks treatment of mild adult asthma with 1,200 $\mu \mathrm{g} \cdot \mathrm{day}^{-1}$ of inhaled budesonide attenuated to the same extent the bronchial hyperresponsiveness to bradykinin and histamine [101]. In children, treatment with 400 $\mu \mathrm{g} \cdot \mathrm{day}^{-1}$ of inhaled beclomethasone dipropionate (BDP) for three months had no significant effect on hyperresponsiveness to either bradykinin or methacholine, in contrast to a decrease in bronchial reactivity to AMP [40]. These data support the hypothesis that, in contrast to the adenosine-induced airflow limitation, bradykinin-induced airway narrowing does not involve mast cell activation.

In summary, bradykinin is a potent pro-inflammatory peptide which exerts its effects secondary to stimulation of $\mathrm{C}$-fibre endings and the release of TKs. Therefore, this challenge is currently used to examine the role of axon reflexes under various experimental conditions, e.g. following allergen challenge [4]. The development of specific nonpeptide bradykinin receptor antagonists will lead to both an increased understanding of the importance of kinins as asthma mediators and to potentially useful therapies [72]. However, the high cost of these peptides will probably limit their use to research purposes.

\section{Sodium metabisulphite and sulphur dioxide}

Sulphur dioxide $\left(\mathrm{SO}_{2}\right)$ and sulphites are fairly ubiquitous: $\mathrm{SO}_{2}$ is a common air pollutant, and sulphites including metabisulphite (MBS), bisulphite, and sulphite are commonly used in the processing and storage of foods and drinks. In addition, sulphites are also formed in the atmosphere as a reaction product of $\mathrm{SO}_{2}$ and water droplets $[102,103]$. When dissolved in water, such as in the mucous membrane lining of the airways, these sulphur substances enter into a $\mathrm{pH}$-dependent equilibrium with one another. Sulphur dioxide and metabisulphite convert to bisulphite, and bisulphite in turn enters into equilibrium with sulphite [103]. The airflow limitating effects of sodium sulphite aerosols were clearly $\mathrm{pH}$-dependent, with the greatest effects occurring at the most acid $\mathrm{pH}$ tested ( $\mathrm{pH} 4)$; however, acidity per se does not appear to be the stimulus to airflow limitation. Rather than exerting a direct effect, decreasing $\mathrm{pH}$ most likely increases the effects by altering the relative concentrations of sulphite, bisulphite and $\mathrm{SO}_{2}$ gas. Bisulphite and $\mathrm{SO}_{2}$ seem to be more potent than sulphite [103].

The ability of inhaled $\mathrm{SO}_{2}$ to produce airflow limitation has been recognized for decades. Brief exposure (10 min) to 5 parts per million (ppm) $\mathrm{SO}_{2}$ or more increases airway resistance in healthy volunteers [104]. Subjects with mild asthma develop airflow limitation at a lower threshold concentration of $\mathrm{SO}_{2}$ and with greater magnitude than do nonasthmatic subjects [105]. Inhaled sulphite aerosols are a stimulus to airflow limitation in subjects with asthma. This effect of sulphite is not restricted to patients with a clinical history of sulphite sensitivity or to subjects who demonstrate sensitivity to oral ingestion of metabisulphite $[103,106]$.

The characteristics of the responses to inhaled MBS are very similar to those seen following inhalation of $\mathrm{SO}_{2}$, suggesting that MBS acts by release of $\mathrm{SO}_{2}$. The shape of the dose-response curves to $\mathrm{SO}_{2}$ [107] and MBS [108] are characteristically steep. The time course of responses to MBS and $\mathrm{SO}_{2}$ are also similar. Onset of the response occurs within the first minute of inhalation and reaches a maximum within $2-5 \mathrm{~min}$. Offset is relatively rapid, the lung function returning to within $10 \%$ of baseline within $30 \min [105,108,109]$.

Refractoriness to MBS challenge has been described in several studies [110-112]. Inhibitory prostaglandins, such as $\mathrm{PGE}_{2}$ may play a role, as treatment with indomethacin induces a small reduction in refractoriness [110]. In addition, cross refractoriness between MBS and exercise challenge has been shown; it was hypothesized that the common component may also involve the generation of inhibitory prostanoids [113].

Pretreatment with the histamine $\mathrm{H}_{1}$ receptor antagonist terfenadine had no influence on MBS-induced airflow limitation, which argues against a role for histamine in the mechanism of MBS-induced airflow limitation [114]. Cyclooxygenase products appear to contribute to a limited extent to the airway response to $\mathrm{SO}_{2}$ [112] and MBS [24], as nonsteroidal anti-inflammatory drugs (NSAIDs) slightly attenuate the induced airflow limitation. The source of prostanoids that contribute to the bronchoconstrictive 
response to $\mathrm{SO}_{2}\left(\mathrm{PGD}_{2}, \mathrm{PGF}_{2 \alpha}\right.$ and $\left.\mathrm{TX}\right)$ remains undetermined. A single oral dose $(20 \mathrm{mg})$ of the leukotriene receptor antagonist zafirlukast attenuated $\mathrm{SO}_{2}$-induced bronchoconstriction in patients with asthma, implying that leukotriene release is also involved [115].

A role for vagal reflex pathways is suggested by the protective actions of anticholinergic drugs in some studies $[104,105,112,116]$. Other authors, using other methodology and dosing did not confirm these findings [117] or detected protective effects in only some of their tested subjects. A few studies have looked into the possibility of release of sensory neuropeptides (SP and NKA), following MBS inhalation. Inhalation of the NEP inhibitor thiorphan was found to increase airflow limitation to inhaled MBS in normal subjects, suggesting that tachykinins are involved [118]. In contrast, oral administration of the NEP inhibitor acetorphan did not affect inhaled MBS-induced airflow limitation in atopic asthmatics [119]. The contribution of tachykinins has not yet been specifically been investigated in man. In guinea pigs in vivo, it was shown that both antagonists for the $\mathrm{NK}_{1}$ (CP 96,345 ) and $\mathrm{NK}_{2}$ (SR 48968) tachykinin receptors inhibited airflow limitation induced by inhaled MBS [120]. These results are compatible with the hypothesis that MBS stimulates sensory nerves, leading to airflow limitation by noncholinergic as well as cholinergic pathways.

It has been shown that $4 \mathrm{mg}$ of inhaled nedocromil sodium is more effective than $10 \mathrm{mg}$ of inhaled SCG in preventing MBS- [121] and $\mathrm{SO}_{2}$-induced airflow limitation [30] in asthmatics or nonasthmatic, atopic subjects. Both drugs are known to stabilize mast cells and to inhibit airway afferent nerve activity. Pretreatment with the nitric oxide (NO) synthase inhibitor L-NMMA did not affect MBS-induced bronchoconstriction and refractoriness suggesting that endogenous NO-production is unlikely to be involved in the airway response to MBS [122]. Inhaled furosemide attenuates MBS-induced airflow limitation in asthmatics; this effect appears to be independent from interaction with the $\mathrm{Na} / \mathrm{K} / \mathrm{Cl}$ cotransporter protein or with carbonic anhydrase $[123,124]$. It has been suggested that furosemide acts by promoting production of bronchoprotective prostaglandins such as $\mathrm{PGE}_{2}$ in the airway [124]; however, the one report in which this hypothesis was specifically tested in the setting of MBS-induced airflow limitation failed to confirm this [125]. On the other hand, inhalation of $100 \mu \mathrm{g}$ of $\mathrm{PGE}_{2}$ did provide considerable protection against MBS-induced airflow limitation, while having only little or no effect on methacholine-induced airflow limitaton [126].

Inhalation of heparin did not protect against MBS and methacholine challenge in asthma, arguing against an inhibitory effect on neural pathways or airway smooth muscle [127]. Conversely, inhaled magnesium sulphate was shown to mildly attenuate MBS-induced airflow limitation in asthmatics; its mechanism of action is as yet not established. One hypothesis states that $\mathrm{Mg}^{++}$would interfere with $\mathrm{Ca}^{++}$handling of the bronchial smooth muscle cells [128].

Pretreatment with $2,000 \mu \mathrm{g}$ of inhaled beclomethasone dipropionate per day for a mean duration of 26 days, a course enough to significantly reduce airway responsiveness to histamine, methacholine and isocapnic hyperventilation of air, has no consistent effect on $\mathrm{SO}_{2}$-induced airflow limitation [129]. Inhaled budesonide $(800 \mu \mathrm{g}$ b.d.) for 14 days reduced airway responsiveness to MBS and methacholine to a similar degree ( $\sim 1$ doubling dose), but this effect was significantly smaller than the reduction of responsiveness to AMP [39].

In summary, $\mathrm{SO}_{2}$ is a common air pollutant, which is considered to be a stimulus to investigate the role of cholinergic and/ or noncholinergic neural pathways in airway narrowing. Instead of administering gaseous $\mathrm{SO}_{2}$ it is much simpler to aerosolize sodium $\mathrm{MBS}$, a $\mathrm{SO}_{2}$ generating solution [3]. $\mathrm{SO}_{2}$ and MBS challenges may be used to distinguish asthma from chronic obstructive pulmonary disease, but this needs further investigation [130]. The lack of sound reproducibility studies for this challenge may hamper interpretation of the data obtained with MBS and $\mathrm{SO}_{2}$.

\section{Propranolol ( $\beta$-blockers)}

When given by inhalation, propranolol induces airflow limitation in asthmatic patients but not in normal subjects $[131,132]$. Bronchial responsiveness to inhaled propranolol, measured as PD20, is safely measurable in nearly all $(>95 \%)$ children and adults with asthma and this response is reproducible [133]. Peak propranolol-induced airflow limitation is reached within $2-3 \mathrm{~min}$, persists for $\sim 20 \mathrm{~min}$ and is followed by a gradual and spontaneous recovery over a period of at least $1 \mathrm{~h}$ [131]. It has been shown that the decrease in FEV1 after propranolol challenge did not return within $5 \%$ of baseline values after 90 min [134]. The effect of propranolol inhalation on FEV1 even lasts for up to $8 \mathrm{~h}$ and counteracts the normal diurnal variation in FEV1 in most asthmatics. This makes propranolol challenge tests less suitable for studying indirect bronchial responsiveness within one day and makes it impossible to determine whether tachyphylaxis occurs following repeated propranolol challenge with a time interval up to $8 \mathrm{~h}$ [135]. Measurement of propranolol responsiveness appears to be reproducible from day to day when these tests are repeated within a time interval of one week [136].

The mechanism of $\beta$-blocker-induced airflow limitation in asthmatic patients is still not fully understood. Beta receptor blockade appears to be involved, as the L-isomer of infused propranolol causes airflow limitation, whereas the $\mathrm{D}$-isomer, which is without significant $\beta$-receptor blocking activity, does not [137].

The evidence regarding involvement of mast cells in propranolol-induced airflow limitation is limited and conflicting [137-139]. Pretreatment with the cys $\mathrm{LT}_{1}$ receptor antagonist pranlukast did not protect against propranololinduced bronchoconstriction, suggesting that cysteinyl leukotrienes are not involved [140]. $\beta$-blocker-induced airflow limitation involves cholinergic mechanisms. Indeed, anticholinergic agents are protective against the propranolol challenge; moreover, they reverse the ongoing airflow limitation $[131,141,142]$. In patients with more severe asthma there may be additional mechanisms by which $\beta$-blockers cause airflow limitation. A role for sensory nerve hyperresponsiveness has been proposed [143], based on the results of work on animals.

The effects obtained with inhaled cromones are variable, with positive effects being reported with $20 \mathrm{mg}$ of diSCG [144], and borderline, nonsignificant protection with a dose of $10 \mathrm{mg}$ of diSCG and nedocromil sodium [145]. 
Furosemide (40 mg nebulized) also attenuates propranolol-induced airflow limitation [146]. Inhaled corticosteroids, given as 4 weeks of treatment with daily doses of $1,000 \mathrm{mg}$ of beclomethasone dipropionate [134] or with $400 \mu \mathrm{g}$ of budesonide [147], did not reduce the bronchial responsiveness to inhaled propranolol.

In summary, bronchial challenges with propranolol are currently essentially of pathophysiological relevance.

\section{Physical stimuli}

\section{Exercise}

The occurrence and severity of exercise-induced bronchoconstriction (EIB) depend on the level of ventilation reached and sustained during exercise, the water content and the temperature of the air inspired during exercise, and the interval since exercise last induced an attack of asthma. In the pulmonary function laboratory, EIB can be demonstrated in $70 \%$ to $80 \%$ of patients with asthma who exercise at $40-60 \%$ of their predicted maximum voluntary ventilation for 6-8 min while breathing room air. The maximal airflow limitation is usually recorded within 3-12 min after exercise. The majority of patients recover spontaneously from EIB within $30 \mathrm{~min}$. The severity of EIB cannot be predicted from the resting level of lung function. EIB may occur at any age and is equally common in adults and children [4, 148].

It is thought that EIB is initiated by the abnormally high rate of water loss from the airways in bringing large volumes of air to alveolar conditions in a relatively short time. Water loss from the respiratory tract results in both cooling of the larger airways and dehydration of the mucosa lining these airways [148]. The mechanisms by which water loss induces airway narrowing in asthma are thought to be a transient hyperosmolarity of the periciliary fluid [149] and/or a transient oedema of the airway wall [150]. It is now acknowledged that airway cooling per se is not essential for EIB to occur; the critical event would be the rate of rewarming the airways during recovery from hyperpnoea. The vascular hypothesis of EIB suggests that the bronchial circulation vasoconstricts in response to airway cooling, and on cessation of hyperpnoea reactive hyperaemia and oedema of the airway wall occur, due to rapid expansion of the blood volume in peribronchial vascular plexi [150]. The osmolarity hypothesis, in contrast, suggests that the abnormally high rate of evaporative water loss from the airways during exer- cise and hyperventilation causes an increase in ion concentration of the periciliary fluid and that hyperosmolarity of this fluid acts as the stimulus to EIB [149]. The precise pathway by which an increase in osmolarity leads to airflow limitation is not known. It has been shown that bronchoconstrictor mediators are released in response to a hyperosmolar stimulus. Mast cells and epithelial cells are the likely source of these mediators [151]. In addition, neural pathways may also be activated directly by changes in airways osmolarity and temperature and/or by the mediators released in response to these same stimuli, resulting in reflex bronchoconstriction and increased microvascular permeability and oedema [148].

The refractory period after EIB, has been defined as the time during which less than half of the initial airway response will be provoked by a second challenge. Approximately $50 \%$ of patients are refractory to a second exercise challenge performed within 60 min [4, 148]; when the interval between exercise tests increases to $3 \mathrm{~h}$ the initial bronchial response returns in most subjects [152]. Exercise and hypertonic saline challenges were found to induce refractoriness interchangeably, suggesting that they produced a refractory period through a very similar pathway [153].

Repeated adenosine 5'-monophosphate (AMP) inhalation challenge induces tachyphylaxis to AMP [13]. The finding that repeated AMP bronchoprovocation also attenuates subsequent responsiveness to exercise suggests a shared mechanism of refractoriness [154]. This common mechanism may be related to mast cell mediator release, being induced both by AMP [16] and by hypertonic stimulation [151].

A contribution of histamine to EIB has been demonstrated using histamine $\mathrm{H}_{1}$ receptor antagonists, of which terfenadine $(60-180 \mathrm{mg})$ has been most extensively studied [155-158] (table 3). Prostanoids also appear to play a role in eliciting EIB. Oral pretreatment with $150 \mathrm{mg}$ of the cyclo-oxygenase inhibitor flurbiprofen attenuates EIB [158]. Although oral administration of indomethacin did not alter airflow limitation after exercise $[159,160]$, pretreatment with inhaled indomethacin significantly attenuated EIB [161]. Furthermore, the inhalation of $100 \mu \mathrm{g}$ of $\mathrm{PGE}_{2}$ [162] or of $250-500 \mu \mathrm{g}$ of prostacyclin $\left(\mathrm{PGI}_{2}\right)$ [163] was also effective in inhibiting EIB. Oral pretreatment with the TX prostanoid receptor antagonists GR32191 [164] and BAY u 3405 [165], however, did not modulate EIB, thus not supporting a role for contractile prostanoids acting through the TP receptor.

Table 3. - Inhibitory effects of drugs on the airflow limitation, induced by physical stimuli in asthma

\begin{tabular}{|c|c|c|c|c|}
\hline & Exercise & Hypertonic saline & Distilled water & Isocapnic hyperventilation \\
\hline $\mathrm{H}_{1}$-antagonists & + & + & + & + \\
\hline 5-LO-I/Cys $\mathrm{LT}_{1}$ antagonists/FLAP-I & +++ & $\mathrm{ND}$ & ++ & ++ \\
\hline COX-I & ++ & + & ++ & - \\
\hline Anticholinergics & $++*$ & $++^{*}$ & $++^{*}$ & $++*$ \\
\hline TK-antagonists & + & - & ND & $\mathrm{ND}$ \\
\hline SCG/NED & +++ & +++ & +++ & +++ \\
\hline Furosemide & ++ & ++ & ++ & ++ \\
\hline Heparin & +++ & $\mathrm{ND}$ & $\mathrm{ND}$ & ND \\
\hline iGCS & ++ & ++ & ++ & ++ \\
\hline
\end{tabular}

Cys $\mathrm{LT}_{1}$ : cysteinyl leukotriene 1 receptor; FLAP-I: 5-lipoxygenase activating protein inhibitor; TK: tachykinins; SCG: sodium cromoglycate; NED: nedocromil sodium; iGCS: inhaled glucocorticosteroids; *: wide individual variations; ND: no data available; +: inhibitory effect; -: no inhibitory effect. 
Since the report, in which the intravenously administered cysLT ${ }^{1}$ antagonist MK-571 was shown to markedly attenuate EIB [166], cysteinyl leukotrienes have been recognized as major mediators in EIB. Subsequent studies, assessing pretreatment with 5-lipoxygenase inhibitors, such as zileuton [167] or ABT-761 (atreleuton) [22, $168]$, or with cysLT ${ }_{1}$ receptor antagonists, such as zafirlukast (ICI 204,219) [169], SK\&F 104353 [170], or montelukast (MK-0476) [171, 172] consistently confirmed these findings.

Neural factors are also implicated in the pathogenesis of EIB. The fact that clinically used doses of inhaled ipratropium bromide exert a protective effect, suggests that cholinergic mechanisms also contribute to EIB [173-175]. There is a wide interindividual variation in the response to anticholinergic drugs; their protective effects appear to be more marked in those patients in whom the main site of airflow limitation is in the large central airways [176]. The possible involvement of the excitatory nonadrenergic/noncholinergic (NANC) system in EIB was studied in a clinical trial with administration of a tachykinin receptor antagonist. Inhalation of $2.5 \mathrm{mg}$ of FK-888, a tachykinin $\mathrm{NK}_{1}$ receptor antagonist, administered as dry powder, did not significantly attenuate the maximal fall in specific airway conductance, but did shorten the recovery phase [177].

SCG and NED have been shown to be effective in up to $80 \%$ of patients with EIB [178-180]. Increasing the dose of SCG from 2-20 mg via MDI increases its protective effect [181]; such a dose dependency was not found for doses, ranging from 0.5 to $20 \mathrm{mg} \cdot \mathrm{mL}^{-1}$ nebulized nedocromil sodium, suggesting that these doses already lie near the top of the dose response curve [182]. The duration of their protective effect is $\sim 2 \mathrm{~h}[178,180]$.

Nebulized furosemide attenuates EIB in a dose-dependent fashion [183]. The finding that pretreatment with the cox inhibitor indomethacin diminishes the protective effect of nebulized furosemide suggests that the beneficial effects of the latter are due to production of inhibitory prostanoids, such as $\mathrm{PGE}_{2}$ [184]. Nebulized HMWH LMWH prevents EIB $[185,186]$. The mechanism underlying the protective effect of inhaled heparin is not known. In vitro, heparin has been shown to act as a specific blocker of inositol 1,4,5-triphosphate $\left(\mathrm{IP}_{3}\right)$-binding to its receptors and to inhibit $\mathrm{IP}_{3}$-induced $\mathrm{Ca}++$ release.

Finally, several studies demonstrated that continuous treatment with inhaled steroids for periods of at least 3 weeks afford significant partial protection against EIB, in children [187, 188] as well as in adults [189].

In summary, it is generally accepted that exercise is the bronchial challenge test that most closely resembles the circumstances which an asthmatic patient is likely to encounter in their everyday life. In clinical situations, exercise tests are not very sensitive, but are highly specific for the diagnosis of asthma, and are particularly useful in children, army recruits and athletes. In addition, the challenge is also very interesting from a pathophysiological point of view, and is a useful challenge in the evaluation of various antiasthmatic medications $[4,148]$.

\section{Aerosols of hypertonic saline}

Hyperosmolar aerosols are potent stimuli for airflow limitation in asthmatics, whereas normal subjects only rarely react [190-194]. The osmolarity of the solution appears to be the most important determinant of the airway response: the more hypertonic the nebulized solution becomes, the bigger the airway response [190]. Although hyperosmolarity by itself is a cause of airflow limitation, it was subsequently shown that excess ion concentration is an additional factor contributing to the response [195]. Furthermore, it is likely that the type of ion used is also an important factor, as it was found that $10 \% \mathrm{KCl}$ (molarity, 1.34) is more potent than $10 \% \mathrm{NaCl}$ (molarity, 1.73) [44].

The methodology of the challenge has been standardized. A concentration of $4.5 \%$ saline is most commonly used; $80 \%$ of clinically recognized asthmatics have a PD20 of $\leq 15 \mathrm{~mL}$ [4]. A person who responds to $4.5 \%$ saline usually also has exercise-induced asthma. The osmolarity is slightly above sea water, and the test is also used for screening scuba divers. A suitably prepared dry powder of $\mathrm{NaCl}$ may potentially be an alternative to "wet" $\mathrm{NaCl}$ aerosols [196]. Another hyperosmolar challenge which has been proposed as an alternative for hypertonic $\mathrm{NaCl}$ is a bronchial provocation test using a dry powder of mannitol [197, 198]. A dry powder preparation of mannitol can provoke airflow limitation in asthmatic subjects who are sensitive to a wet aerosol of $4.5 \% \mathrm{NaCl}$ and methacholine, whereas healthy subjects do not react [197]. Asthmatics, responsive to inhalation of dry air during exercise or hyperventilation, are also responsive to inhaled mannitol [198].

The airway response to hypertonic (HS) is usually maximal 1-3 min and, for most persons, the maximum response occurs 60-90 s after exposure. Spontaneous recovery in FEV1 after the challenge occurs for most asthmatics within $30 \mathrm{~min}$ if the fall is $<25 \%$. About half of the patients will have a refractory period after HS challenge [153, 199]. A good concordance has been found between between sensitivity to HS and exercise [153, 200-202]. The sensitivity to HS was not significantly related to ultrasonically nebulized distilled water (UNDW) challenge in adults [203] and in a mixed age group [202], while a good correlation was found in one trial, studying children [204]. These differences may be related to differences in age characteristics as well as to methodological differences, the latter trial [204] using cold UNDW at $4^{\circ} \mathrm{C}$, while water at room temperature was used in both other trials [202, 203]. A good concordance also exists between HS and isocapnic hyperventilation [192, 202].

The finding that the refractory period following HS challenge is characterized by an increase in airways responsiveness to AMP would suggest that HS-induced airflow limitation is not associated with mast cell depletion of preformed mediators [14]. However, it has been shown that human lung mast cells release histamine via a non IgE-mediated pathway following a hyperosmolar stimulus in vitro [151]. In vitro studies on isolated central airways from nonasthmatics have confirmed that a hyperosmolar stimulus releases acetylcholine, histamine and neuropeptides [205]. Release of mediators (histamine, $\mathrm{PGD}_{2}$, and $\mathrm{PGF}_{2 \alpha}$ ) was observed following endobronchial challenge with HS in asthmatics [206], but this was not confirmed by others [207]. In addition, it has been repeatedly shown that $\mathrm{H}_{1}$-antihistamines effectively inhibit HS-induced airflow limitation in asthmatics [208211]. Given the lack of effect of indomethacin [212] and 
the only modest effect of the cox inhibitor flurbiprofen [209], the contribution of prostanoids appears to be minor.

Clinical studies with anticholinergic drugs have all shown protective effects against HS challenge, but with wide variations between subjects $[173,191,213]$. Similarly, nebulized lidocaine hydrochloride inhibits the airway response to HS in some patients, whilst being ineffective in others [213]. A role for sensory nerves in HS challenge was suggested by the finding that $\mathrm{C}$ fibres in dogs were stimulated by injection of hypertonic saline into a lobar bronchus [214]. In other animal models, hypertonic aerosols promote sensory neuropeptide release from $\mathrm{C}$ fibres [215]. Intravenous administration of CP-99,994, an $\mathrm{NK}_{1}$ tachykinin receptor antagonist, did not significantly inhibit HS-induced airflow limitation in subjects with mild asthma [216]; however it is not known whether the dosing used was able to antagonize airway effects of the sensory neuropeptides SP and NKA.

The HS-induced airflow limitation is attenuated following pretreatment with inhaled SCG [173, 191, 217]. Similar effects have been demonstrated with NED [218, $219]$. It is proposed that nedocromil sodium and cromolyn sodium can affect water transport into and out of the epithelial cells by their action on chloride ion channels [219]. Inhaled furosemide is also very protective against HS challenge [220, 221]. These effects were not blocked by pretreatment with indomethacin, suggesting that the protective action of furosemide is not secondary to $\mathrm{PGE}_{2}$ release [221].

Finally, three open studies have dealt with the effect of iGCS on the airway response to HS. In one study, $\sim 8$ weeks of treatment with beclomethasone dipropionate (dose range 600-1,500 $\mu \mathrm{g} \cdot$ day $^{-1}$ ) attenuated the bronchial responsiveness [222]. In a second study, similar results were obtained following 24-56 days of $1,000 \mathrm{mg}$ of budesonide per day [217]. In a third trial, 1,000 mg budesonide. day ${ }^{-1}$ during 20 weeks, attenuated the responsiveness for HS more than that for histamine, the difference just failing to reach statistical significance [223].

The bronchial challenge using HS is mainly of pathophysiological importance. Challenge with HS is easier and cheaper to use because expensive equipment and a source of dry air is not required as with exercise or hyperventilation. The ability to obtain a dose-response curve rather than a single response and the ability to collect inflammatory cells at the same time ("induced sputum") make challenge with HS an attractive technique [224]. Diving with a snorkel or self-contained underwater breathing apparatus (scuba) is a situation in which the patient with asthma may be at risk, as accidental inhalation of seawater is common. HS challenge is therefore useful for assessing persons with a past history of asthma who wish to scuba dive, in order to identify those persons at increased risk [225].

\section{Aerosols of ultrasonically nebulized distilled water}

In 1968, it was reported that the inhalation of an aerosol of distilled water could induce an increase in airflow limitation in patients with asthma [226]. Aerosols of distilled water (fog) have been used for bronchial provocation testing in both adults and children. Although a number of different techniques have been described, a standardized procedure has been proposed. The protocol has many points in common with that for bronchoprovocation with inhalation of hypertonic saline aerosols [4]. Ultrasonic nebulizers are recommended for the generation of hypotonic aerosols; distilled water is most commonly used (UNDW) [227].

Normal subjects only rarely experience airflow limitation upon inhalation of UNDW, while the majority of asthmatics do $[155,190,228,229]$. Changing the temperature of the inhaled water from body temperature $\left(36^{\circ} \mathrm{C}\right)$ to room temperature $\left(22^{\circ} \mathrm{C}\right)$ results in similar changes in airflow limitation [191]. The more hypotonic the inhaled solution becomes, the stronger the stimulus for inducing airflow limitation [190]. It is not the lack of ions in distilled water that causes airflow limitation, but its lack of osmolarity: distilled water (which lacks both ions and osmolarity) causes airflow limitation, whereas a solution of dextrose in water (which also lacks ions but is iso-osmolar) only rarely induces airflow limitation [195]. When equivalent doses of water were inhaled on two occasions, 40 min apart, a phenomenon of refractoriness was detected [191]. About half of the patients are refractory to the effects of repeated UNDW challenge and this phenomenon can persist for at least $2 \mathrm{~h}$ after the initial UNDW challenge [230]. This refractoriness is inhibited by pretreatment with oral indomethacin [231].

It has consistently been found that airway responsiveness to inhaled methacholine [203, 230, 232-234] and histamine [233] is increased 40-60 min after challenge with UNDW; the clinical relevance of these small increases, however, is uncertain. This increase in sensitivity is not related to the bronchoconstrictor effect of the water [200] and is blocked by prior inhalation of SCG [234]. A good concordance was found between UNDW and exercise challenge [235-237]. A strong correlation between the airway responses to UNDW and cold air hyperventilation was found in one trial [238], but not in three other studies [239-241].

Histamine is involved in bronchoconstriction induced by UNDW. Human peripheral blood basophils release histamine upon exposure to water in vitro [242]. H1antihistamines were reported to attenuate the airflow limitation induced by UNDW [210, 211,243]. The role of cox products has been studied by several authors. A pretreatment with oral indomethacin did not significantly affect the airway responsiveness to UNDW, but it did prevent the occurrence of a refractory period [231]. Oral aspirin was shown to prevent UNDW-induced airflow limitation in a dose-related manner [244]. The inhaled route appears to provide an even better and longer lasting protection, lysine acetylsalicylate (L-ASA) being more effective than indomethacin [245]. Pretreatment with inhaled $\mathrm{PGE}_{1}$ and $\mathrm{PGE}_{2}$ [228] or $\mathrm{PGI}_{2}$ (prostacyclin) [163] also has protective effects. A contribution of leukotrienes is suggested by the attenuating effect of a single oral dose of the 5-lipoxygenase inhibitor zileuton [246].

Anticholinergic drugs have been shown to have protective effects against UNDW challenge, but only in a part of the patients [191, 228, 247-251]. In all studies there was a wide variation in the response to these drugs. Interestingly, morphine sulphate inhibits the UNDWinduced airflow limitation in those asthmatics whose responses are inhibited by atropine, and this effect is 
reversed by the opiate receptor antagonist naloxone. This suggests that opiate receptor stimulation by morphine causes inhibition of the vagally mediated component of water-induced airflow limitation [252]. A role for sensory nerves in UNDW challenge was suggested from experiments in dogs [214] and guinea-pigs [253].

Several studies have consistently confirmed the protective effects of inhaled SCG [191, 228, 235, 247, 249, 250, $254,255]$. Only a few authors have studied the effects of inhaled nedocromil sodium, obtaining similar results $[254,256,257]$. In contrast with corticosteroids, the protective effect of SCG and NED is immediate. NED does not appear to have a long-lasting effect after 8 weeks of administration, as it did not significantly influence the airway reactivity to UNDW, $24 \mathrm{~h}$ after it had been discontinued [258]. Several studies have also confirmed the effectiveness of inhaled furosemide in preventing UNDWinduced airflow limitation [255, 259].

Finally, the effects of prolonged treatments with inhaled corticosteroids were studied in two clinical trials. Beclomethasone dipropionate, given via pMDI at a dose of 800 $\mu \mathrm{g}$ daily, significantly reduced the airway responsiveness to UNDW after 4 and 8 weeks treatment [258]. In a second trial, 6 weeks treatment with fluticasone propionate 750 $\mu \mathrm{g}$ daily was found to be as effective as beclomethasone dipropionate $1,500 \mu \mathrm{g}$ daily, both given via pMDI [260].

In summary, at the present time, challenges with UNDW are essentially of pathophysiological interest.

\section{Isocapnic hyperventilation}

Although the original description of hyperventilation (HV)-induced airflow limitation was made in 1946 [261], renewed interest in this method for inducing airflow limitation occurred because of the recognition that HVinduced cooling and/or drying of the airways is the key mechanism of EIB. The precise manner in which the isocapnic hyperventilation (IHV) challenge is performed influences the magnitude of the induced airflow limitation [262]. The major determinants of its magnitude are: the minute ventilation during HV [263], the duration of the challenge [264], and the temperature and the water content of the inspired air [265]. It has been shown that the degree of airflow limitation following IHV is dependent upon the duration of hyperventilation [264]. The time until maximal airflow limitation following cessation of HV varies from 5-15 min, and appears shorter as the duration of the challenge increases [264, 266].

The IHV challenge is to be considered a laboratory nearequivalent of exercise as a bronchoprovocative stimulus. Several IHV protocols have been described; their principle is based on the subject breathing conditioned air, following a protocol for stepwise increase in minute ventilation [4]. Most asthmatics develop airflow limitation upon breathing frigid dry air at high minute ventilation. This corresponds to the clinical observation that some asthmatics develop airflow limitation by walking in cold weather. In contrast to asthmatics, normal subjects are much less sensitive to cold air hyperventilation [193, 267-270].

An important percentage of subjects display a refractory period, following IHV challenge [262, 271-273]; as already mentioned, indomethacin blocks the refractory period to exercise, but not to IHV [160]. A good concordance exists between HS and IHV [192, 202]. Four studies have looked into the correlation between the airway responses to UNDW and cold air hyperventilation [238-241]. A strong correlation was found in only one trial [238], wheras three other studies were unable to detect a significant correlation [239-241].

In general, there is a correlation between the medications which attenuate EIA and those which attenuate $\mathrm{IHV}$-induced airflow limitation. The $\mathrm{H}_{1}$-antihistamine terfenadine attenuated IHV-induced airflow limitation in adults [274, 275], but not in children [156]. Hyperventilation was found to stimulate the release of $\mathrm{PGI}_{2}$ and $\mathrm{PGE}_{2}$ in healthy subjects [276]; however, cox products do not seem to play an important role, as the COX-inhibitors indomethacin [160] and flurbiprofen [275] failed to modify the responses to IHV. Similarly, the PAF antagonist BN 52063 proved to be ineffective [277]. Cysteinyl leukotrienes, on the other hand, do seem to be relevant mediators. Elevated levels of $\mathrm{LTC}_{4}, \mathrm{D}_{4}$, and $\mathrm{E}_{4}$ were detected in bronchoalveolar lavage fluid of asthmatics, immediately after performing IHV challenge. Moreover, pretreatment with the 5-lipoxygenase inhibitors A-64077 [278] and zileuton [279], and with the 5-lipoxygenase activating protein inhibitor BAYx 1005 [280] consistently produced significant blunting of the IHV challenge.

Inhaled anticholinergic drugs partially protect against the challenge, but there are wide variations between subjects [281-283]. The role of sensory C fibres in IHVinduced airflow limitation, using specific tachykinin receptor antagonists, has not yet been specifically studied in man. The participation of both $\mathrm{NK}_{1}$ and $\mathrm{NK}_{2}$ receptors in a guinea pig model of IHV, however, has been established [284].

Both SCG [283, 285-287] and NED [286, 287] have shown to be effective in reducing airway responses to $\mathrm{IHV}$; the duration of the protective effect, however, is short [287]. Furosemide has been shown to be an effective agent against IHV challenge, in both adults [288, 289] and children [290].

Finally, 4-6 weeks of treatment with inhaled corticosteroids also attenuate the airway hyperresponsiveness to IHV; this has been shown with doses of 1,000-2,000 $\mu \mathrm{g}$ of beclomethasone $[129,291]$ as well as with $1,600 \mu \mathrm{g}$ of budesonide [189], all given via metered-dose inhaler (pMDI).

In summary, IHV challenge reproduces the symptoms produced by exercise. The complex technical requirements, however, limit its widespread application [4].

\section{Implications for future research}

The airway narrowing in asthma is the ultimate result of an interaction between complex and multiple mechanisms not necessarily and uniquely related to airway inflammation [292]. In spite of this fact, BHR in asthma is associated with ongoing airway inflammation and can therefore be considered as a physiological marker of acute as well as chronic inflammation. The results of the different bronchial challenge tests are only weakly correlated and therefore not mutually interchangeable, each test implicitly providing different and perhaps complementary information on the multiple pathways leading to airway narrowing [4].

Among the indirect challenges the physical stimuli have been widely studied and some of them have been well 
standardized [4, 5]. For some of the pharmacological indirect stimuli (e.g. MBS, bradykinin, propranolol) there is a need for better standardization. Although measurements of airway responsiveness have a good safety record $[4,224,293]$, severe bronchoconstriction can occur and a case of fatal asthma has been described after nebulization of UNDW [294].

It has been suggested that indirectly acting bronchial stimuli would better reflect the degree of airway inflammation than directly acting stimuli [41]. Limited data has been published on this subject. A number of studies suggest that adenosine (AMP) might be a potentially useful marker [43], with a closer relationship to the underlying acute inflammatory process than methacholine to the early asthmatic response following allergen challenge [295] or to allergen avoidance [42]. It has also been shown that sputum eosinophilia is more closely associated with airway responsiveness to bradykinin than to methacholine [296].

The number of papers, comparing the effect of antiinflammatory medication on an indirect as well as on a direct stimulus in the same patients is currently very small. In all of them, inhaled glucocorticosteroids were used, and this during periods varying from 2-20 weeks, thus assessing the potential early anti-inflammatory benefits of this class of drugs. Again, adenosine appeared to be a better marker than a directly acting stimulus [39, 40]. Other trials, comparing a direct stimulus with bradykinin $[40$, 101], exercise [189] or IHV [129, 189] failed to detect significant differences. More work needs to be performed in order to more conclusively confirm the validity of the concept that indirect stimuli are more sensitive markers of airway inflammation, to identify the most suitable bronchial stimulus to be used, and to clarify the issue whether assessing early anti-inflammatory effects of certain drug classes is of clinical relevance to the management of asthmatic patients. An European Respiratory Society Task Force is currently developping recommendations on the use of indirect challenges in the diagnosis and monitoring of asthma, and the results should become available within the next year.

Acknowledgements. The authors thank C. Vandeven and C. Nelis for help in preparing the manuscript.

\section{References}

1. Pauwels R. Bronchial Hyperresponsiveness. In: Kay AB, ed. Allergy and allergic disease. Oxford, Blackwell Science, 1997; pp. 682-691.

2. Pauwels R, Joos G, Van der Straeten M. Bronchial hyperresponsiveness is not bronchial hyperresponsiveness is not bronchial asthma. Clin Allergy 1988; 18: 317-321.

3. Rogers DF, O'Connor BJ. Airway hyperresponsiveness relation to asthma and inflammation. Thorax 1993; 48: 1095-1096.

4. Sterk PJ, Fabbri LM, Quanjer PhH, et al. Airway responsiveness. Standardized challenge testing with pharmacological, physical and sensitizing stimuli in adults. Report Working Party Standardization of Lung Function Tests. European Community for Steel and Coal. Official position of the European Respiratory Society. Eur Respir $J$ 1993; 6 Suppl 16: 53-83.

5. American Thoracic Society. Guidelines for methacholine and exercise challenge testing-1999. Am J Respir Crit Care Med 2000; 161: 309-329.

6. Dent G, Rabe KF. Adenosine. In: Leff AR. Pulmonary and critical care pharmacology and therapeutics. New York, McGraw-Hill, 1996; pp. 173-180.

7. Fredholm BB, Arslan G, Kull B, Kontny E, Svenningsson P. Adenosine (P1) receptor signalling. Drug Dev Res 1996; 39: 262-268.

8. Joos G, Pauwels RA. Adenosine receptors involved in the bronchoconstrictor effect of adenosine. Drug Dev Res 1996; 39: 330-332.

9. Feoktistov I, Polosa R, Holgate ST, Biaggioni I. Adenosine A2B receptors: a novel therapeutic target in asthma? Trends Pharmacol Sci 1998; 19: 148-153.

10. Cushley MJ, Tattersfield AE, Holgate ST. Inhaled adenosine and guanosine on airway resistance in normal and asthmatic subjects. Br J Clin Pharmacol 1983; 15: 161165.

11. Phillips GD, Ng WH, Church MK, Holgate ST. The response of plasma histamine to bronchoprovocation with methacholine, adenosine $5^{\prime}$-monophosphate, and allergen in atopic nonasthmatic subjects. Am Rev Respir Dis 1990; 141: 9-13.

12. Chan W, Cushley MJ, Holgate ST. The effect of inhaled adenosine $5^{\prime}$-monophosphate (AMP) on airway calibre in normal and asthmatic subjects. Clin Sci 1986; 70: 65P66P.

13. Daxun Z, Rafferty P, Richards R, Summerell S, Holgate ST. Airway refractoriness to adenosine $5^{\prime}$-monophosphate after repeated inhalation. J Allergy Clin Immunol 1989; 83: $152-158$.

14. O'Hickey SP, Rees PJ, Lee TH. Airway responsiveness to adenosine $5^{\prime}$ monophosphate following inhalation of hypertonic saline. Eur Respir J 1989; 2: 923-928.

15. Hughes PJ, Holgate ST, Church MK. Adenosine inhibits and potentiates IgE-dependent histamine release from human lung mast cells by an A2-purinoceptor mediated mechanism. Biochem Pharmacol 1984; 33: 3847-3852.

16. Peachell PT, Columbo M, Kagey-Sobotka A, Lichtenstein LM, Marone G. Adenosine potentiates mediator release from human lung mast cells. Am Rev Respir Dis 1988; 138: 1143-1151.

17. Polosa R, Ng WH, Crimi N, et al. Release of mast-cellderived mediators after endobronchial adenosine challenge in asthma. Am J Respir Crit Care Med 1995; 151: 624-629.

18. Driver AG, Kukoly CA, Metzger WJ, Mustafa SJ. Bronchial challenge with adenosine causes the release of serum neutrophil chemotactic factor in asthma. Am Rev Respir Dis 1991; 143: 1002-1007.

19. Björck T, Gustafsson LE, Dahlen SE. Isolated bronchi from asthmatics are hyperresponsive to adenosine, which apparently acts indirectly by liberation of leukotrienes and histamine. Am Rev Respir Dis 1992; 145: 1087-1091.

20. Rafferty P, Beasley R, Holgate ST. The contribution of histamine to immediate bronchoconstriction provoked by inhaled allergen and adenosine $5^{\prime}$ monophosphate in atopic asthma. Am Rev Respir Dis 1987; 136: 369-373.

21. Phillips GD, Rafferty P, Beasley R, Holgate ST. Effect of oral terfenadine on the bronchoconstrictor response to inhaled histamine and adenosine $5^{\prime}$-monophosphate in non-atopic asthma. Thorax 1987; 42: 939-945.

22. Van Schoor J, Joos GF, Kips JC, Drajesk JF, Carpentier PJ, Pauwels RA. The effect of ABT-761, a novel 5lipoxygenase inhibitor, on exercise- and adenosine-induced bronchoconstriction in asthmatic subjects. $\mathrm{Am} J$ Respir Crit Care Med 1997; 155: 875-880. 
23. Crimi N, Polosa R, Magri S, et al. Inhaled lysine acetylsalicylate (L-ASA) attenuates the bronchoconstrictor response to adenosine 5'-monophosphate (AMP) in asthmatic subjects. Eur Respir J 1995; 8: 905-912.

24. Wang M, Wisniewski A, Pavord I, Knox A, Tattersfield A. Comparison of three inhaled non-steroidal anti-inflammatory drugs on the airway response to sodium metabisulphite and adenosine 5'- monophosphate challenge in asthma. Thorax 1996; 51: 799-804.

25. Crimi N, Palermo F, Polosa R, et al. Effect of indomethacin on adenosine-induced bronchoconstriction. $J$ Allergy Clin Immunol 1989; 83: 921-925.

26. Phillips GD, Holgate ST. The effect of oral terfenadine alone and in combination with flurbiprofen on the bronchoconstrictor response to inhaled adenosine 5'- monophosphate in nonatopic asthma. Am Rev Respir Dis 1989; 139: 463-469.

27. Polosa R, Phillips GD, Rajakulasingam K, Holgate ST. The effect of inhaled ipratropium bromide alone and in combination with oral terfenadine on bronchoconstriction provoked by adenosine $5^{\prime}$ - monophosphate and histamine in asthma. J Allergy Clin Immunol 1991; 87: 939-947.

28. Crimi N, Palermo F, Oliveri R, Polosa R, Settinieri I, Mistretta A. Protective effects of inhaled ipratropium bromide on bronchoconstriction induced by adenosine and methacholine in asthma. Eur Respir J 1992; 5: 560565.

29. Polosa R, Santonocito G, Magri S, et al. Neutral endopeptidase inhibition with inhaled phosphoramidon: no effect on bronchial responsiveness to adenosine 5 '-monophosphate (AMP) in asthma. Eur Respir $J$ 1997; 10: 2460-2464.

30. Altounyan REC, Lee TB, Rocchiccioli MS, Shaw CL. A comparison of the inhibitory effects of nedocromil sodium and SCG on adenosine monophosphate-induced bronchoconstriction in atopic subjects. Eur J Respir Dis 1986; 69 (Suppl. 147): 277-279.

31. Crimi N, Palermo F, Oliveri R, et al. Comparative study of the effects of nedocromil sodium (4 mg) and SCG (10 $\mathrm{mg}$ ) on adenosine-induced bronchoconstriction in asthmatic subjects. Clin Allergy 1988; 18: 367-374.

32. Richards R, Phillips GD, Holgate ST. Nedocromil sodium is more potent than SCG against AMP- induced bronchoconstriction in atopic asthmatic subjects. Clin Exp Allergy 1989; 19: 285-291.

33. Norris AA, Alton EW. Chloride transport and the action of SCG and nedocromil sodium in asthma. Clin Exp Allergy 1996; 26: 250-253.

34. Taylor DA, McGrath JL, Orr LM, Barnes PJ, O'Connor BJ. Effect of endogenous nitric oxide inhibition on airway responsiveness to histamine and adenosine- 5 '-monophosphate in asthma. Thorax 1998; 53: 483-489.

35. Polosa R, Lau LC, Holgate ST. Inhibition of adenosine 5'monophosphate- and methacholine-induced bronchoconstriction in asthma by inhaled frusemide. Eur Respir $J$ 1990; 3: 665-672.

36. Rajakulasingam K, Polosa R, Church MK, Howarth PH, Holgate ST. Effect of inhaled frusemide on responses of airways to bradykinin and adenosine 5'-monophosphate in asthma. Thorax 1994; 49: 485-491.

37. Polosa R, Magri S, Vancheri C, et al. Time course of changes in adenosine 5 '-monophosphate airway responsiveness with inhaled heparin in allergic asthma. J Allergy Clin Immunol 1997; 99: 338-344.

38. Ceyhan BB, Celikel T. Effect of inhaled heparin on adenosine-induced bronchial hyperreactivity. Int $J$ Clin Pharmacol Ther 1997; 35: 208-213.
39. O'Connor BJ, Ridge SM, Barnes PJ, Fuller RW. Greater effect of inhaled budesonide on adenosine 5'-monophosphate- induced than on sodium-metabisulfite-induced bronchoconstriction in asthma. Am Rev Respir Dis 1992; 146: 560-564.

40. Doull L, Sandall D, Smith S, Schreiber J, Freezer NJ, Holgate ST. Differential inhibitory effect of regular inhaled corticosteroid on airway responsiveness to adenosine $5^{\prime}$ monophosphate, methacholine, and bradykinin in symptomatic children with recurrent wheeze. Pediatr Pulmonol 1997; 23: 404-411.

41. Rogers DF, O'Connor BJ. Airway hyperresponsiveness: relation to asthma and inflammation? Thorax 1993; 48: 1095-1096.

42. Benckhuijsen J, van den Bos JW, van Velzen E, de Bruijn $\mathrm{R}$, Aalbers R. Differences in the effect of allergen avoidance on bronchial hyperresponsiveness as measured by methacholine, adenosine 5 ' - monophosphate, and exercise in asthmatic children. Pediatr Pulmonol 1996; 22: 147-153.

43. Polosa R, Holgate ST. Adenosine bronchoprovocation: a promising marker of allergic inflammation in asthma? Thorax 1997; 52: 919-923.

44. Joos GF, Germonpre PR, Kips JC, Peleman RA, Pauwels RA. Sensory neuropeptides and the human lower airways: present state and future directions. Eur Respir J 1994; 7 : 1161-1171.

45. Barnes PJ. Sensory peptides and airway diseases. In: Geppetti P, Holzer P. Neurogenic inflammation. Boca Raton, CRC Press, 1996; pp. 169-185.

46. Maggi CA. The effects of tachykinins on inflammatory and immune cells. Regul Pept 1997; 70: 75-90.

47. Ho WZ, Lai JP, Zhu XH, Uvaydova M, Douglas SD. Human monocytes and macrophages express substance $\mathrm{P}$ and neurokinin-1 receptor. J Immunol 1997; 159: 5654-5660.

48. Maggi CA. Tachykinin receptors and airway pathophysiology. Eur Respir J 1993; 6: 735-742.

49. Naline E, Devillier P, Drapeau G, et al. Characterization of neurokinin effects and receptor selectivity in human isolated bronchi. Am Rev Respir Dis 1989; 140: 679-686.

50. Advenier C, Naline E, Toty L, et al. Effects on the isolated human bronchus of SR 48968, a potent and selective nonpeptide antagonist of the neurokinin A (NK2) receptors. Am Rev Respir Dis 1992; 146: 1177-1181.

51. Ellis JL, Undem BJ, Kays JS, Ghanekar SV, Barthlow HG, Buckner CK. Pharmacological examination of receptors mediating contractile responses to tachykinins in airways isolated from human, guinea pig and hamster. $J$ Pharmacol Exp Ther 1993; 267: 95-101.

52. Naline E, Molimard M, Regoli D, Emonds-Alt X, Bellamy JF, Advenier C. Evidence for functional tachykinin NK1 receptors on human isolated small bronchi. Am J Physiol 1996; 271: L763-L767.

53. Di Maria GU, Bellofiore S, Geppetti P. Regulation of airway neurogenic inflammation by neutral endopeptidase. Eur Respir J 1998; 12: 1454-1462.

54. Nadel JA. Peptidase modulation of neurogenic inflammation. In: Geppetti P, Holzer P. Neurogenic Inflammation. Boca Raton, CRC Press, 1996; pp. 115-127.

55. Joos G, Pauwels R, Van der Straeten M. Effect of inhaled substance $\mathrm{P}$ and neurokinin A on the airways of normal and asthmatic subjects. Thorax 1987; 42: 779-783.

56. Crimi N, Palermo F, Oliveri R, et al. Effect of nedocromil on bronchospasm induced by inhalation of substance $\mathrm{P}$ in asthmatic subjects. Clin Allergy 1988; 18: 375-382.

57. Cheung D, Bel EH, den Hartigh J, Dijkman JH, Sterk PJ. The effect of an inhaled neutral endopeptidase inhibitor, 
thiorphan, on airway responses to neurokinin A in normal humans in vivo. Am Rev Respir Dis 1992; 145: 12751280 .

58. Cheung D, Timmers MC, Zwinderman AH, den Hartigh J, Dijkman JH, Sterk PJ. Neutral endopeptidase activity and airway hyperresponsiveness to neurokinin A in asthmatic subjects in vivo. Am Rev Respir Dis 1993; 148: $1467-1473$.

59. Nakai S, Iikura Y, Akimoto K, Shiraki K. Substance Pinduced cutaneous and bronchial reactions in children with bronchial asthma. Ann Allergy 1991; 66: 155-161.

60. Crimi N, Palermo F, Oliveri R, Polosa R, Magri S, Mistretta A. Inhibition of neutral endopeptidase potentiates bronchoconstriction induced by neurokinin $\mathrm{A}$ in asthmatic patients. Clin Exp Allergy 1994; 24: 115-120.

61. Joos GF, Van Schoor J, Kips JC, Pauwels RA. The effect of inhaled FK224, a tachykinin NK-1 and NK-2 receptor antagonist, on neurokinin A-induced bronchoconstriction in asthmatics. Am J Respir Crit Care Med 1996; 153: 1781-1784.

62. Van Schoor J, Joos GF, Chasson BL, Brouard RJ, Pauwels RA. The effect of the NK2 tachykinin receptor antagonist SR 48968 (saredutant) on neurokinin Ainduced bronchoconstriction in asthmatics. Eur Respir $J$ 1998; 12: 17-23.

63. Crimi N, Palermo F, Oliveri R, et al. Influence of antihistamine (astemizole) and anticholinergic drugs (ipratropium bromide) on bronchoconstriction induced by substance P. Ann Allergy 1990; 65: 115-120.

64. Crimi N, Oliveri R, Polosa R, Palermo F, Mistretta A. The effect of oral terfenadine on neurokinin-A-induced bronchoconstriction. J Allergy Clin Immunol 1993; 91: 10961098.

65. Ali H, Leung KB, Pearce FL, Hayes NA, Foreman JC. Comparison of the histamine-releasing action of substance $\mathrm{P}$ on mast cells and basophils from different species and tissues. Int Arch Allergy Appl Immunol 1986; 79: 413-418.

66. Heaney LG, Cross LJ, Stanford CF, Ennis M. Substance P induces histamine release from human pulmonary mast cells. Clin Exp Allergy 1995; 25: 179-186.

67. Crimi N, Polosa R, Prosperini G, Magri S, Ciamarra I, Mistretta A. Changes in neurokinin A airway responsiveness with inhaled lysine-acetylsalicylate in asthma. Eur Respir J 1996; 9: 1139-1145.

68. Joos G, Pauwels R, Van der Straeten M. The effect of oxitropium bromide on neurokinin A-induced bronchoconstriction in asthmatic subjects. Pulm Pharmacol 1988; 1: 41-45.

69. Joos GF, Pauwels RA, Van der Straeten ME. The effect of nedocromil sodium on the bronchoconstrictor effect of neurokinin A in subjects with asthma. J Allergy Clin Immunol 1989; 83: 663-668.

70. Crimi N, Prosperini G, Ciamarra I, Mastruzzo C, Magri S, Polosa R. Changes in neurokinin A (NKA) airway responsiveness with inhaled frusemide in asthma. Thorax 1997; 52: 775-779.

71. Van Schoor J, Joos G, Pauwels RA. The effects of inhaled fluticasone propionate on methacholine- and neurokinin A-induced bronchoconstriction in asthmatics. $\mathrm{Am} \mathrm{J}$ Respir Crit Care Med 1999; 159: A880.

72. Proud D. Kinins as mediators of lung disease. In: Crystal RG, West JB, Barnes PJ, Weibel ER. The Lung. Philadelphia, Lippincott Raven, 1997; pp. 89-101.

73. Herxheimer H, Stresemann E. The effect of bradykinin aerosol in guinea-pigs and in man. $J$ Physiol 1961; 158: 38P-39P.
74. Varonier HS, Panzani R. The effect of inhalations of bradykinin on healthy and atopic (asthmatic) children. Int Arch Allergy Appl Immunol 1968; 34: 293-296.

75. Simonsson BG, Skoogh BE, Bergh NP, Andersson R, Svedmyr N. In vivo and in vitro effect of bradykinin on bronchial motor tone in normal subjects and patients with airways obstruction. Respiration 1973; 30: 378-388.

76. Fuller RW, Dixon CM, Cuss FM, Barnes PJ. Bradykinininduced bronchoconstriction in humans. Mode of action. Am Rev Respir Dis 1987; 135: 176-180.

77. Polosa R, Holgate ST. Comparative airway response to inhaled bradykinin, kallidin, and [des- Arg9] bradykinin in normal and asthmatic subjects. Am Rev Respir Dis 1990; 142: 1367-1371.

78. Berman AR, Liu MC, Wagner EM, Proud D. Dissociation of bradykinin-induced plasma exudation and reactivity in the peripheral airways. Am J Respir Crit Care Med 1996; 154: 418-423.

79. Molimard M, Martin CA, Naline E, Hirsch A, Advenier C. Contractile effects of bradykinin on the isolated human small bronchus. Am J Respir Crit Care Med 1994; 149: 123-127.

80. Hulsmann AR, Raatgeep HR, Saxena PR, Kerrebijn KF, de Jongste JC. Bradykinin-induced contraction of human peripheral airways mediated by both bradykinin B-2 and thromboxane prostanoid receptors. Am J Respir Crit Care Med 1994; 150: 1012-1018.

81. Crimi N, Polosa R, Pulvirenti G, et al. Effect of an inhaled neutral endopeptidase inhibitor, phosphoramidon, on baseline airway calibre and bronchial responsiveness to bradykinin in asthma. Thorax 1995; 50: 505-510.

82. Polosa R, Rajakulasingam K, Prosperini G, Milazzo LV, Santonocito G, Holgate ST. Cross-tachyphylactic airway response to inhaled bradykinin, kallidin and [desArg9]bradykinin in asthmatic subjects. Eur Respir J 1993; 6: 687-693.

83. Schmidt D, Jorres RA, Rabe KF, Magnussen H. Tachyphylaxis of airway response to inhaled bradykinin over several days. Pneumologie 1996; 50: 779-782.

84. Rajakulasingam K, Church MK, Howarth PH, Holgate ST. Factors determining bradykinin bronchial responsiveness and refractoriness in asthma. J Allergy Clin Immunol 1993; 92: 140-142.

85. Rajakulasingam K, Makker HK, Howarth PH, Holgate ST. Cross refractoriness between bradykinin and hypertonic saline challenges in asthma. J Allergy Clin Immunol 1995; 96: 502-509.

86. Polosa R, Phillips GD, Lai CK, Holgate ST. Contribution of histamine and prostanoids to bronchoconstriction provoked by inhaled bradykinin in atopic asthma. Allergy 1990; 45: 174-182.

87. Pang L, Knox AJ. $\mathrm{PGE}_{2}$ release by bradykinin in human airway smooth muscle cells: involvement of cyclooxygenase-2 induction. Am J Physiol 1997; 273: L1132L1140.

88. Polosa R, Milazzo VL, Magri S, et al. Activity of inhaled lysine acetylsalicylate (L-ASA) on bradykinin- induced bronchoconstriction in asthmatics: evidence of contribution of prostaglandins. Eur Respir J 1997; 10: 866-871.

89. Polosa R, Lai CK, Robinson C, Holgate ST. The influence of cyclooxygenase inhibition on the loss of bronchoconstrictor response to repeated bradykinin challenge in asthma. Eur Respir J 1990; 3: 914-921.

90. Molimard M, Martin CA, Naline E, Hirsch A, Advenier C. Role of thromboxane A2 in bradykinin-induced human isolated small bronchi contraction. Eur J Pharmacol 1995; 278: 49-54. 
91. Rajakulasingam K, Johnston SL, Ducey J, Ritter W, Howarth PH, Holgate ST. Effect of thromboxane A2receptor antagonist on bradykinin-induced bronchoconstriction in asthma. J Appl Physiol 1996; 80: 1973-1977.

92. Geppetti P. Sensory neuropeptide release by bradykinin: mechanisms and pathophysiological implications. Regul Pept 1993; 47: 1-23.

93. Ichinose M, Belvisi MG, Barnes PJ. Bradykinin-induced bronchoconstriction in guinea pig in vivo: role of neural mechanisms. J Pharmacol Exp Ther 1990; 253: 594-599.

94. Saria A, Martling CR, Yan Z, Theodorsson-Norheim E, Gamse R, Lundberg JM. Release of multiple tachykinins from capsaicin-sensitive sensory nerves in the lung by bradykinin, histamine, dimethylphenyl piperazinium, and vagal nerve stimulation. Am Rev Respir Dis 1988; 137: 1330-1335.

95. Ichinose $\mathrm{M}$, Nakajima $\mathrm{N}$, Takahashi $\mathrm{T}$, Yamauchi $\mathrm{H}$, Inoue $\mathrm{H}$, Takishima $\mathrm{T}$. Protection against bradykinininduced bronchoconstriction in asthmatic patients by neurokinin receptor antagonist. Lancet 1992; 340: 12481251.

96. Schmidt D, Jorres RA, Rabe KF, Magnussen H. Reproducibility of airway response to inhaled bradykinin and effect of the neurokinin receptor antagonist FK-224 in asthmatic subjects. Eur J Clin Pharmacol 1996; 50: 269273.

97. Dixon CMS, Barnes PJ. Bradykinin-induced bronchoconstriction: inhibition by nedocromil sodium and SCG. $\mathrm{Br} \mathrm{J}$ Clin Pharmacol 1989; 27: 831-836.

98. Dixon M, Jackson DM, Richards IM. The action of SCG on ' $\mathrm{C}$ ' fibre endings in the dog lung. Br J Pharmacol 1980; 70: 11-13.

99. Ricciardolo FL, Geppetti P, Mistretta A, et al. Randomised double-blind placebo-controlled study of the effect of inhibition of nitric oxide synthesis in bradykinininduced asthma. Lancet 1996; 348: 374-377.

100. Molimard M, Naline E, Hirsch A, Advenier C. Furosemide inhibits bradykinin-induced contraction of human bronchi: role of thromboxane A2 receptor antagonism. Eur J Pharmacol 1995; 278: 253-256.

101. Fuller RW, Choudry NB, Eriksson G. Action of budesonide on asthmatic bronchial hyperresponsiveness. Effects on directly and indirectly acting bronchoconstrictors. Chest 1991; 100: 670-674.

102. Peroni DG, Boner AL. Sulfite sensitivity. Clin Exp Allergy 1995; 25: 680-681.

103. Fine JM, Gordon T, Sheppard D. The roles of $\mathrm{pH}$ and ionic species in sulfur dioxide- and sulfite- induced bronchoconstriction. Am Rev Respir Dis 1987; 136: 11221126.

104. Nadel JA, Salem H, Tamplin B, Tokiwa Y. Mechanism of bronchoconstriction during inhalation of sulfur dioxide. $J$ Appl Physiol 1965; 20: 164-167.

105. Sheppard D, Wong WS, Uehara CF, Nadel JA, Boushey HA. Lower threshold and greater bronchomotor responsiveness of asthmatic subjects to sulfur dioxide. Am Rev Respir Dis 1980; 122: 873-878.

106. Schwartz HJ, Chester EH. Bronchospastic responses to aerosolized metabisulfite in asthmatic subjects: potential mechanisms and clinical implications. J Allergy Clin Immunol 1984; 74: 511-513.

107. Harries MG, Parkes PE, Lessof MH, Orr TS. Role of bronchial irritant receptors in asthma. Lancet 1981; 1: 57.

108. Wright W, Zhang YG, Salome CM, Woolcock AJ. Effect of inhaled preservatives on asthmatic subjects. I. Sodium metabisulfite. Am Rev Respir Dis 1990; 141: 1400-1404.
109. Frank NR, Amdur MO, Worcester J, Whittenberger JL. Effects of acute controlled exposure to $\mathrm{SO}_{2}$ on respiratory mechanisms in healthy male adults. J Appl Physiol 1962; 17: 252-258.

110. Pavord ID, Wisniewski A, Tattersfield AE. Refractoriness to inhaled sodium metabisulphite in subjects with mild asthma. Eur Respir J 1994; 7: 50-54.

111. Sheppard D, Epstein J, Bethel RA, Nadel JA, Boushey HA. Tolerance to sulfur dioxide-induced bronchoconstriction in subjects with asthma. Environ Res 1983; 30: 412-419.

112. Field PI, Simmul R, Bell SC, Allen DH, Berend N. Evidence for opioid modulation and generation of prostaglandins in sulphur dioxide (SO)2-induced bronchoconstriction. Thorax 1996; 51: 159-163.

113. Pavord I, Lazarowicz H, Inchley D, Baldwin D, Knox A, Tattersfield A. Cross refractoriness between sodium metabisulphite and exercise induced asthma. Thorax 1994; 49: 245-249.

114. Dixon CMS. Metabisulphite induced bronchoconstriction: mechanisms. Am Rev Respir Dis 1988; 137: A238.

115. Lazarus SC, Wong HH, Watts MJ, Boushey HA, Lavins BJ, Minkwitz MC. The leukotriene receptor antagonist zafirlukast inhibits sulfur dioxide- induced bronchoconstriction in patients with asthma. Am J Respir Crit Care Med 1997; 156: 1725-1730.

116. Bellingan GJ, Dixon CM, Ind PW. Inhibition of inhaled metabisulphite-induced bronchoconstriction by inhaled frusemide and ipratropium bromide. Br J Clin Pharmacol 1992; 34: 71-74.

117. Nichol GM, Nix A, Chung KF, Barnes PJ. Characterisation of bronchoconstrictor responses to sodium metabisulphite aerosol in atopic subjects with and without asthma. Thorax 1989; 44: 1009-1014.

118. Bellofiore S, Caltagirone F, Pennisi A, Ciancio N, Mistretta A, Di Maria GU. Neutral endopeptidase inhibitor thiorphan increases airway narrowing to inhaled sodium metabisulfite in normal subjects. Am J Respir Crit Care Med 1994; 150: 853-856.

119. Nichol GM, O'Connor BJ, Lecomte JM, Chung KF, Barnes PJ. Effect of neutral endopeptidase inhibitor on airway function and bronchial responsiveness in asthmatic subjects. Eur J Clin Pharmacol 1992; 42: 491-494.

120. Sakamoto T, Tsukagoshi H, Barnes PJ, Chung KF. Involvement of tachykinin receptors $\left(\mathrm{NK}_{1}\right.$ and $\left.\mathrm{NK}_{2}\right)$ in sodium metabisulfite-induced airway effects. Am J Respir Crit Care Med 1994; 149: 387-391.

121. Dixon CMS, Ind PW. Inhaled sodium metabisulphite induced bronchoconstriction: inhibition by nedocromil sodium and SCG. Br J Clin Pharmacol 1990; 30: 371-376.

122. Hamad AM, Wisniewski A, Range SP, Small T, Holland F, Knox AJ. The effect of the nitric oxide synthase inhibitor, L-NMMA, on sodium metabisulphite-induced bronchoconstriction and refractoriness in asthma. Eur Respir J 1999; 14: 702-705.

123. Nichol GM, Alton EW, Nix A, Geddes DM, Chung KF, Barnes PJ. Effect of inhaled furosemide on metabisulfiteand methacholine-induced bronchoconstriction and nasal potential difference in asthmatic subjects. Am Rev Respir Dis 1990; 142: 576-580.

124. Pye S, Pavord I, Wilding P, Bennett J, Knox A, Tattersfield A. A comparison of the effects of inhaled furosemide and ethacrynic acid on sodium-metabisulfiteinduced bronchoconstriction in subjects with asthma. $\mathrm{Am}$ J Respir Crit Care Med 1995; 151: 337-339.

125. O'Connor BJ, Barnes PJ, Chung KF. Inhibition of sodium metabisulphite induced bronchoconstriction by frusemide 
in asthma: role of cyclooxygenase products. Thorax 1994; 49: $307-311$.

126. Pavord ID, Wisniewski A, Mathur R, Wahedna I, Knox AJ, Tattersfield AE. Effect of inhaled prostaglandin E2 on bronchial reactivity to sodium metabisulphite and methacholine in patients with asthma. Thorax 1991; 46: 633637.

127. Pavord I, Mudassar T, Bennett J, Wilding P, Knox A. The effect of inhaled heparin on bronchial reactivity to sodium metabisulphite and methacholine in patients with asthma. Eur Respir J 1996; 9: 217-219.

128. Nannini LJJ, Hofer D. Effect of inhaled magnesium sulfate on sodium metabisulfite-induced bronchoconstriction in asthma. Chest 1997; 111: 858-861.

129. Wiebicke W, Jorres R, Magnussen H. Comparison of the effects of inhaled corticosteroids on the airway response to histamine, methacholine, hyperventilation, and sulfur dioxide in subjects with asthma. J Allergy Clin Immunol 1990; 86: 915-923.

130. Woolcock AJ, Anderson SD, Peat JK, et al. Characteristics of bronchial hyperresponsiveness in chronic obstructive pulmonary disease and in asthma. Am Rev Respir Dis 1991; 143: 1438-1443.

131. Okayama M, Yafuso N, Nogami H, et al. A new method of inhalation challenge with propranolol: comparison with methacholine-induced bronchoconstriction and role of vagal nerve activity. J Allergy Clin Immunol 1987; 80: 291-299.

132. Gerritsen J, Koeter GH, Vander Weele LT, Knol K. Propranolol inhalation challenge in relation to histamine response in children with asthma. Thorax 1988; 43: 451455.

133. Foresi A, Chetta A, Pelucchi A, Mastropasqua B, Moretti D, Olivieri D. Bronchial responsiveness to inhaled propranolol in asthmatic children and adults. Eur Respir $J$ 1993; 6: 181-188.

134. Carpentiere G, Castello F, Marino S. Effect of beclomethasone dipropionate on the bronchial responsiveness to propranolol in asthmatics. Chest 1990; 98: 263-265.

135. Oosterhoff Y, Koeter GH, Postma DS. Effects of propranolol inhalation on the diurnal increase in FEV1 and on propranolol airways responsiveness in atopic subjects with asthma. Thorax 1995; 50: 937-940.

136. Foresi A, Chetta A, Corbo GM, Cuomo A, Olivieri D. Provocative dose and dose-response curve to inhaled propranolol in asthmatic patients with bronchial hyperresponsiveness to methacholine. Chest 1987; 92: 455-459.

137. Ind PW, Barnes PJ, Durham SR, Kay AB. Propranololinduced bronchoconstriction in asthma: beta-receptor blockade and mediator release. Am Rev Respir Dis 1984; 129 Suppl: A10.

138. Ind PW, Barnes PJ, Brown MJ, Dollery CT. Plasma histamine concentration during propranolol induced bronchoconstriction. Thorax 1985; 40: 903-909.

139. Carpentiere G, Castello F, Marino S. Effect of oral terfenadine on the bronchoconstrictor response to inhaled propranolol and histamine in asthmatics. Curr Ther Res 1991; 49: 507-513.

140. Fujimura M, Abo M, Kamio Y, et al. Effect of leukotriene and thromboxane antagonist on propranolol-induced bronchoconstriction. Am J Respir Crit Care Med 1999; 160: 2100-2103.

141. Ind PW, Dixon CM, Fuller RW, Barnes PJ. Anticholinergic blockade of beta-blocker-induced bronchoconstriction. Am Rev Respir Dis 1989; 139: 1390-1394.

142. Koeter GH, Meurs H, Jonkman JH, et al. Protective effect of oral oxyphenonium bromide, terbutaline and theo- phylline against the bronchial obstructive effects of inhaled histamine, acetylcholine and propranolol. Eur $J$ Clin Pharmacol 1984; 26: 435-441.

143. Belvisi M. Beta-blocker induced asthma: a role for sensory nerve hyperresponsiveness? Clin Exp Allergy 1996; 26: $1343-1346$.

144. Koeter GH, Meurs H, de Monchy JG, de Vries K. Protective effect of diSCG on propranolol challenge. Allergy 1982; 37: 587-590.

145. Foresi A, Chetta A, Pelucchi A, Cavigioli G, Mastropasqua B, Olivieri D. Effect of inhaled diSCG and nedocromil sodium on propranolol-induced bronchoconstriction. Ann Allergy 1993; 70: 159-163.

146. Myers JD, Higham MA, Shakur BH, Wickremasinghe M, Ind PW. Attenuation of propranolol-induced bronchoconstriction by frusemide. Thorax 1997; 52: 861-865.

147. Kraan J, Koeter GH, Mark TW, Sluiter HJ, de Vries K. Changes in bronchial hyperreactivity induced by 4 weeks of treatment with antiasthmatic drugs in patients with allergic asthma: a comparison between budesonide and terbutaline. J Allergy Clin Immunol 1985; 76: 628-636.

148. Anderson SD. Exercise-induced asthma. In: Middleton E, Reed CE, Ellis EF, Adkinson NF, Yunginger JW, Busse WW. eds. Allergy: principles and practice. St. Louis, Mosby, 1993; pp. 1343-1347.

149. Anderson SD. Is there a unifying hypothesis for exerciseinduced asthma? J Allergy Clin Immunol 1984; 73: 660665.

150. McFadden ERJ. Hypothesis: exercise-induced asthma as a vascular phenomenon. Lancet 1990; 335: 880-883.

151. Eggleston PA, Kagey-Sobotka A, Lichtenstein LM. A comparison of the osmotic activation of basophils and human lung mast cells. Am Rev Respir Dis 1987; 135: 1043-1048.

152. Edmunds AT, Tooley M, Godfrey S. The refractory period after exercise-induced asthma: its duration and relation to the severity of exercise. Am Rev Respir Dis 1978; 117: 247-254.

153. Belcher NG, Rees PJ, Clark TJ, Lee TH. A comparison of the refractory periods induced by hypertonic airway challenge and exercise in bronchial asthma. Am Rev Respir Dis 1987; 135: 822-825.

154. Finnerty JP, Polosa R, Holgate ST. Repeated exposure of asthmatic airways to inhaled adenosine 5 '- monophosphate attenuates bronchoconstriction provoked by exercise. J Allergy Clin Immunol 1990; 86: 353-359.

155. Patel KR. Terfenadine in exercise induced asthma. $B M J$ 1984; 288: 1496-1497.

156. Wiebicke W, Poynter A, Montgomery M, Chernick V, Pasterkamp H. Effect of terfenadine on the response to exercise and cold air in asthma. Pediatr Pulmonol 1988; 4: 225-229.

157. Pierson WE, Furukawa CT, Shapiro GG, Altman LC, Bierman CW. Terfenadine blockade of exercise-induced bronchospasm. Ann Allergy 1989; 63: 461-464.

158. Finnerty JP, Holgate ST. Evidence for the roles of histamine and prostaglandins as mediators in exerciseinduced asthma: the inhibitory effect of terfenadine and flurbiprofen alone and in combination. Eur Respir J 1990; 3: $540-547$.

159. O'Byrne PM, Jones GL. The effect of indomethacin on exercise-induced bronchoconstriction and refractoriness after exercise. Am Rev Respir Dis 1986; 134: 69-72.

160. Margolskee DJ, Bigby BG, Boushey HA. Indomethacin blocks airway tolerance to repetitive exercise but not to eucapnic hyperponea in asthmatic subjects. Am Rev Respir Dis 1988; 137: 842-846. 
161. Shimizu T, Mochizuki H, Shigeta M, Morikawa A. Effect of inhaled indomethacin on exercise-induced bronchoconstriction in children with asthma. Am J Respir Crit Care Med 1997; 155: 170-173.

162. Melillo E, Woolley KL, Manning PJ, Watson RM, $\mathrm{O}^{\prime}$ Byrne PM. Effect of inhaled $\mathrm{PGE}_{2}$ on exercise-induced bronchoconstriction in asthmatic subjects. Am J Respir Crit Care Med 1994; 149: 1138-1141.

163. Bianco S, Robuschi M, Ceserani R, Gandolfi C. Effects of prostacyclin on aspecifically and specifically induced bronchoconstriction in asthmatic patients. Eur J Respir Dis 1980; 106 (Suppl. 106): 81-87.

164. Finnerty JP, Twentyman OP, Harris A, Palmer JB, Holgate ST. Effect of GR32191, a potent thromboxane receptor antagonist, on exercise induced bronchoconstriction in asthma. Thorax 1991; 46: 190-192.

165. Magnussen $\mathrm{H}$, Boerger $\mathrm{S}$, Templin $\mathrm{K}$, Baunack AR. Effects of a thromboxane-receptor antagonist, BAY u 3405 , on prostaglandin D2- and exercise-induced bronchoconstriction. J Allergy Clin Immunol 1992; 89: 11191126.

166. Manning PJ, Watson RM, Margolskee DJ, Williams VC, Schwartz JI, O'Byrne PM. Inhibition of exercise-induced bronchoconstriction by MK-571, a potent leukotriene D4receptor antagonist. N Engl J Med 1990; 323: 1736-1739.

167. Meltzer SS, Hasday JD, Cohn J, Bleecker ER. Inhibition of exercise-induced bronchospasm by zileuton: a 5lipoxygenase inhibitor. Am J Respir Crit Care Med 1996; 153: 931-935.

168. Lehnigk B, Rabe KF, Dent G, Herst RS, Carpentier PJ, Magnussen H. Effects of a 5-lipoxygenase inhibitor, ABT-761, on exercise-induced bronchoconstriction and urinary LTE4 in asthmatic patients. Eur Respir J 1998; 11: $617-623$.

169. Finnerty JP, Wood-Baker R, Thomson H, Holgate ST. Role of leukotrienes in exercise-induced asthma. Inhibitory effect of ICI 204219, a potent leukotriene D4 receptor antagonist. Am Rev Respir Dis 1992; 145: 746749.

170. Robuschi M, Riva E, Fuccella LM, et al. Prevention of exercise-induced bronchoconstriction by a new leukotriene antagonist (SK\&F 104353). A double-blind study versus diSCG and placebo. Am Rev Respir Dis 1992; 145 : $1285-1288$

171. Reiss TF, Hill JB, Harman E, et al. Increased urinary excretion of LTE4 after exercise and attenuation of exercise-induced bronchospasm by montelukast, a cysteinyl leukotriene receptor antagonist. Thorax 1997; 52: $1030-1035$.

172. Leff JA, Busse WW, Pearlman D, et al. Montelukast, a leukotriene-receptor antagonist, for the treatment of mild asthma and exercise-induced bronchoconstriction. $N E n g l$ J Med 1998; 339: 147-152.

173. Boulet LP, Turcotte H, Tennina S. Comparative efficacy of salbutamol, ipratropium, and cromoglycate in the prevention of bronchospasm induced by exercise and hyperosmolar challenges. J Allergy Clin Immunol 1989; 83: 882-887.

174. Dorward AJ, Patel KR. A comparison of ketotifen with clemastine, ipratropium bromide and SCG in exerciseinduced asthma. Clin Allergy 1982; 12: 355-361.

175. Tullett WM, Patel KR, Berkin KE, Kerr JW. Effect of lignocaine, SCG, and ipratropium bromide in exerciseinduced asthma. Thorax 1982; 37: 737-740.

176. Thomson NC, Patel KR, Kerr JW. SCG and ipratropium bromide in exercise-induced asthma. Thorax 1978; 33: 694-699.
177. Ichinose M, Miura M, Yamauchi H, et al. A neurokinin 1receptor antagonist improves exercise-induced airway narrowing in asthmatic patients. Am J Respir Crit Care Med 1996; 153: 936-941.

178. König P, Hordvik NL, Kreutz C. The preventive effect and duration of action of nedocromil sodium and cromolyn sodium on exercise-induced asthma (EIA) in adults. J Allergy Clin Immunol 1987; 79: 64-68.

179. Morton AR, Ogle SL, Fitch KD. Effects of nedocromil sodium, cromolyn sodium, and a placebo in exerciseinduced asthma. Ann Allergy 1992; 68: 143-148.

180. de Benedictis FM, Tuteri G, Pazzelli P, Bertotto A, Bruni $\mathrm{L}$, Vaccaro R. Cromolyn versus nedocromil: duration of action in exercise-induced asthma in children. $J$ Allergy Clin Immunol 1995; 96: 510-514.

181. Tullett WM, Tan KM, Wall RT, Patel KR. Dose-response effect of SCG pressurised aerosol in exercise induced asthma. Thorax 1985; 40: 41-44.

182. Albazzaz MK, Neale MG, Patel KR. Dose-response study of nebulised nedocromil sodium in exercise induced asthma. Thorax 1989; 44: 816-819.

183. Bianco S, Vaghi A, Robuschi M, Pasargiklian M. Prevention of exercise-induced bronchoconstriction by inhaled frusemide. Lancet 1988; 2: 252-255.

184. Pavord ID, Wisniewski A, Tattersfield AE. Inhaled frusemide and exercise induced asthma: evidence of a role for inhibitory prostanoids. Thorax 1992; 47: 797-800.

185. Wilson NM, Barnes PJ, Vickers H, Silverman M. Hyperventilation-induced asthma: evidence for two mechanisms. Thorax 1982; 37: 657-662.

186. Ahmed T, Gonzalez BJ, Danta I. Prevention of exerciseinduced bronchoconstriction by inhaled low-molecularweight heparin. Am J Respir Crit Care Med 1999; 160: 576-581.

187. Henriksen JM. Effect of inhalation of corticosteroids on exercise induced asthma: randomised double blind crossover study of budesonide in asthmatic children. $B M J$ 1985; 291: 248-249.

188. Waalkens HJ, van Essen-Zandvliet EE, Gerritsen J, Duiverman EJ, Kerrebijn KF, Knol K. The effect of an inhaled corticosteroid (budesonide) on exercise-induced asthma in children. Dutch CNSLD Study Group. Eur Respir J 1993; 6: 652-656.

189. Vathenen AS, Knox AJ, Wisniewski A, Tattersfield AE. Effect of inhaled budesonide on bronchial reactivity to histamine, exercise, and eucapnic dry air hyperventilation in patients with asthma. Thorax 1991; 46: 811-816.

190. Schoeffel RE, Anderson SD, Altounyan RE. Bronchial hyperreactivity in response to inhalation of ultrasonically nebulised solutions of distilled water and saline. $B M J$ 1981; 283: 1285-1287.

191. Anderson SD, Schoeffel RE, Finney M. Evaluation of ultrasonically nebulised solutions for provocation testing in patients with asthma. Thorax 1983; 38: 284-291.

192. Smith CM, Anderson SD. Hyperosmolarity as the stimulus to asthma induced by hyperventilation? J Allergy Clin Immunol 1986; 77: 729-736.

193. Araki H, Sly PD. Inhalation of hypertonic saline as a bronchial challenge in children with mild asthma and normal children. J Allergy Clin Immunol 1989; 84: 99107.

194. Riedler J, Reade T, Dalton M, Holst D, Robertson C. Hypertonic saline challenge in an epidemiologic survey of asthma in children. Am J Respir Crit Care Med 1994; 150: $1632-1639$.

195. Eschenbacher WL, Boushey HA, Sheppard D. Alteration in osmolarity of inhaled aerosols cause bronchoconstriction 
and cough, but absence of a permeant anion causes cough alone. Am Rev Respir Dis 1984; 129: 211-215.

196. Anderson SD, Spring J, Moore B, et al. The effect of inhaling a dry powder of sodium chloride on the airways of asthmatic subjects. Eur Respir J 1997; 10: 2465-2473.

197. Anderson SD, Brannan J, Spring J, et al. A new method for bronchial-provocation testing in asthmatic subjects using a dry powder of mannitol. Am J Respir Crit Care Med 1997; 156: 758-765.

198. Brannan JD, Koskela H, Anderson SD, Chew N. Responsiveness to mannitol in asthmatic subjects with exercise- and hyperventilation-induced asthma. Am J Respir Crit Care Med 1998; 158: 1120-1126.

199. Rodwell LT, Anderson SD, Spring JF, Seale JP. Indomethacin and airway responsiveness to repeated $4.5 \% \mathrm{NaCl}$ challenges. Eur J Respir Dis 1993; 6 (Suppl. 17): 200 S.

200. Kivity S, Poterman R, Schwarz Y, Soferman R, Topilsky $M$. Changes in sensitivity to methacholine after inhalation with distilled water: the role of the bronchoconstrictive response. Eur Respir J 1995; 8: 253-256.

201. Belcher NG, Lee TH, Rees PJ. Airway responses to hypertonic saline, exercise and histamine challenges in bronchial asthma. Eur Respir J 1989; 2: 44-48.

202. Smith CM, Anderson SD. Inhalational challenge using hypertonic saline in asthmatic subjects: a comparison with responses to hyperpnoea, methacholine and water. Eur Respir J 1990; 3: 144-151.

203. Smith CM, Anderson SD, Black JL. Methacholine responsiveness increases after ultrasonically nebulized water but not after ultrasonically nebulized hypertonic saline in patients with asthma. $J$ Allergy Clin Immunol 1987; 79: 85-92.

204. Wojnarowski C, Storm Van's GK, Riedler J, Eichler I, Gartner C, Frischer T. Comparison of bronchial challenge with ultrasonic nebulized distilled water and hypertonic saline in children with mild-to-moderate asthma. Eur Respir J 1996; 9: 1896-190.

205. Jongejan RC, de Jongste JC, Raatgeep RC, Stijnen T, Bonta IL, Kerrebijn KF. Effects of hyperosmolarity on human isolated central airways. Br J Pharmacol 1991; 102: 931-937.

206. Gravelyn TR, Pan PM, Eschenbacher WL. Mediator release in an isolated airway segment in subjects with asthma. Am Rev Respir Dis 1988; 137: 641-646.

207. Makker HK, Walls AF, Goulding D, et al. Airway effects of local challenge with hypertonic saline in exerciseinduced asthma. Am J Respir Crit Care Med 1994; 149: 1012-1019.

208. O'Hickey SP, Belcher NG, Rees PJ, Lee TH. Role of histamine release in hypertonic saline induced bronchoconstriction. Thorax 1989; 44: 650-653.

209. Finnerty JP, Wilmot C, Holgate ST. Inhibition of hypertonic saline-induced bronchoconstriction by terfenadine and flurbiprofen. Evidence for the predominant role of histamine. Am Rev Respir Dis 1989; 140: 593-597.

210. Finney MJ, Anderson SD, Black JL. Terfenadine modifies airway narrowing induced by the inhalation of nonisotonic aerosols in subjects with asthma. Am Rev Respir Dis 1990; 141: 1151-1157.

211. Rodwell LT, Anderson SD, Seale JP. Inhaled clemastine, an $\mathrm{H} 1$ antihistamine inhibits airway narrowing caused by aerosols of non-isotonic saline. Eur Respir J 1991; 4: $1126-1134$.

212. Hawksworth RJ, O'Hickey SP, Lee TH. The effects of indomethacin on the refractory period to hypertonic saline-induced bronchoconstriction. Eur Respir J 1992; 5: 963-966.
213. Makker HK, Holgate ST. The contribution of neurogenic reflexes to hypertonic saline-induced bronchoconstriction in asthma. J Allergy Clin Immunol 1993; 92: 82-88.

214. Pisarri TE, Jonzon A, Coleridge HM, Coleridge JC. Vagal afferent and reflex responses to changes in surface osmolarity in lower airways of dogs. $J$ Appl Physiol 1992; 73: 2305-2313.

215. Solway J, Leff AR. Sensory neuropeptides and airway function. J Appl Physiol 1991; 71: 2077-2087.

216. Fahy JV, Wong HH, Geppetti P, et al. Effect of an NK1 receptor antagonist (CP-99,994) on hypertonic salineinduced bronchoconstriction and cough in male asthmatic subjects. Am J Respir Crit Care Med 1995; 152: 879-884.

217. Anderson SD, Du Toit JI, Rodwell LT, Jenkins CR. Acute effect of SCG on airway narrowing induced by 4.5 percent saline aerosol. Outcome before and during treatment with aerosol corticosteroids in patients with asthma. Chest 1994; 105: 673-680.

218. Rodwell LT, Anderson SD, du TJ, Seale JP. Nedocromil sodium inhibits the airway response to hyperosmolar challenge in patients with asthma. Am Rev Respir Dis 1992; 146: 1149-1155.

219. Anderson SD, Rodwell LT, Daviskas E, Spring JF, du Toit J. The protective effect of nedocromil sodium and other drugs on airway narrowing provoked by hyperosmolar stimuli: a role for the airway epithelium? $J$ Allergy Clin Immunol 1996; 98: S124-S134.

220. Rodwell LT, Anderson SD, Du Toit JI, Seale JP. The effect of inhaled frusemide on airway sensitivity to inhaled $4.5 \%$ sodium chloride aerosol in asthmatic subjects. Thorax 1993; 48: 208-213.

221. Rodwell LT, Anderson SD, Spring J, Mohamed S, Seale JP. Effect of inhaled frusemide and oral indomethacin on the airway response to hypertonic saline challenge in asthmatic subjects. Thorax 1997; 52: 59-66.

222. Rodwell LT, Anderson SD, Seale JP. Inhaled steroids modify bronchial responses to hyperosmolar saline. Eur Respir J 1992; 5: 953-962.

223. Du Toit JI, Anderson SD, Jenkins CR, Woolcock AJ, Rodwell LT. Airway responsiveness in asthma: bronchial challenge with histamine and $4.5 \%$ sodium chloride before and after budesonide. Allergy Asthma Proc 1997; 18: 7-14.

224. in't Veen JC, Smits HH, Hiemstra PS, Zwinderman AE, Sterk PJ, Bel EH. Lung function and sputum characteristics of patients with severe asthma during an induced exacerbation by double-blind steroid withdrawal. $\mathrm{Am} \mathrm{J}$ Respir Crit Care Med 1999; 160: 93-99.

225. Anderson SD. Exercise-induced asthma and the use of hypertonic saline aerosol as a bronchial challenge. Respirology 1996; 1: 175-181.

226. de Vries K, Booij-Noord $\mathrm{H}$, Van der Lende $\mathrm{R}$, Van Lookeren Campagne JG, Orie NGM. Reactivity of the bronchial tree to different stimuli. Les Bronches 1968; 18: 439-542.

227. Wolfsdorf J, Swift DL, Avery ME. Mist therapy reconsidered; an evaluation of the respiratory deposition of labelled water aerosols produced by jet and ultrasonic nebulizers. Pediatrics 1969; 43: 799-808.

228. Allegra L, Bianco S. Non-specific broncho-reactivity obtained with an ultrasonic aerosol of distilled water. Eur J Respir Dis 1980; 106: suppl 41-49.

229. Hopp RJ, Christy J, Bewtra AK, Nair NM, Townley RG. Incorporation and analysis of ultrasonically nebulized distilled water challenges in an epidemiologic study of asthma and bronchial reactivity. Ann Allergy 1988; 60: 129-133. 
230. Mattoli S, Foresi A, Corbo GM, et al. Refractory period to ultrasonic mist of distilled water: relationship to methacholine responsiveness, atopic status, and clinical characteristics. Ann Allergy 1987; 58: 134-140.

231. Mattoli S, Foresi A, Corbo GM, Valente S, Ciappi G. The effect of indomethacin on the refractory period occurring after the inhalation of ultrasonically nebulized distilled water. J Allergy Clin Immunol 1987; 79: 678-683.

232. Mattoli S, Foresi A, Corbo GM, Valente S, Patalano F, Ciappi G. Increase in bronchial responsiveness to methacholine and late asthmatic response after the inhalation of ultrasonically nebulized distilled water. Chest 1986; 90 : 726-732.

233. Black JL, Schoeffel RE, Sundrum R, Berend N, Anderson $\mathrm{SD}$. Increased responsiveness to methacholine and histamine after challenge with ultrasonically nebulised water in asthmatic subjects. Thorax 1985; 40: 427-432.

234. Black JL, Smith CM, Anderson SD. Cromolyn sodium inhibits the increased responsiveness to methacholine that follows ultrasonically nebulized water challenge in patients with asthma. J Allergy Clin Immunol 1987; 80: 3944.

235. Bascom R, Bleecker ER. Bronchoconstriction induced by distilled water. Sensitivity in asthmatics and relationship to exercise-induced bronchospasm. Am Rev Respir Dis 1986; 134: 248-253.

236. Obata T, Iikura Y. Comparison of bronchial reactivity to ultrasonically nebulized distilled water, exercise and methacholine challenge test in asthmatic children. Ann Allergy 1994; 72: 167-172.

237. Foresi A, Mattoli S, Corbo GM, Polidori G, Ciappi G. Comparison of bronchial responses to ultrasonically nebulized distilled water, exercise, and methacholine in asthma. Chest 1986; 90: 822-826.

238. Fabbri LM, Mapp CE, Hendrick DJ. Comparison of ultrasonically nebulized distilled water and hyperventilation with cold air in asthma. Ann Allergy 1984; 53: 172-177.

239. Galdes-Sebaldt M, McLaughlin FJ, Levison H. Comparison of cold air, ultrasonic mist, and methacholine inhalations as tests of bronchial reactivity in normal and asthmatic children. J Pediatr 1985; 107: 526-530.

240. Lemire TS, Hopp RJ, Bewtra AK, Nair NM, Townley RG. Comparison of ultrasonically nebulized distilled water and cold-air hyperventilation challenges in asthmatic patients. Chest 1989; 95: 958-961.

241. Eichler I, Gotz M, Zarkovic J, Kofinger A. Distilled water challenges in asthmatic children. Comparison of different protocols. Chest 1992; 102: 753-758.

242. Rimmer J, Bryant DH. Effect of hypo- and hyperosmolarity on basophil histamine release. Clin Allergy 1986; 16: 221-230.

243. Hopp RJ, Bewtra AK, Nair NM, Townley RG. Effect of terfenadine on the bronchoconstriction induced by ultrasonically nebulized distilled water. Ann Allergy 1988; 61: 13-16.

244. Robuschi M. Control of the bronchial tone. Respiration 1988; 54 Suppl 1: 100-107.

245. Bianco S, Vaghi A, Pieroni MG, Robuschi M, Refini RM, Sestini P. Protective activity of inhaled nonsteroidal antiinflammatory drugs on bronchial responsiveness to ultrasonically nebulized water. $J$ Allergy Clin Immunol 1992; 90: 833-839.

246. Dekhuijzen PN, Bootsma GP, Wielders PL, van den Berg LR, Festen J, van Herwaarden CL. Effects of single-dose zileuton on bronchial hyperresponsiveness in asthmatic patients treated with inhaled corticosteroids. Eur Respir $J$ 1997; 10: 2749-2753.

247. Tranfa CM, Vatrella A, Parrella R, Bariffi F. Effect of ipratropium bromide and/or SCG pretreatment on waterinduced bronchoconstriction in asthma. Eur Respir $J$ 1995; 8: 600-604.

248. Groot CA, Lammers JW, Festen J, van Herwaarden CL. The protective effects of ipratropium bromide and terbutaline on distilled water-induced bronchoconstriction. Pulm Pharmacol 1994; 7: 59-63.

249. Bianco S, Robuschi M, Damonte C. Drug effect on bronchial response to PGF2 alpha and water inhalation. Eur $J$ Respir Dis 1983; 128 suppl: 213-221.

250. Sheppard D, Rizk NW, Boushey HA, Bethel RA. Mechanism of cough and bronchoconstriction induced by distilled water aerosol. Am Rev Respir Dis 1983; 127: 691-694.

251. Fabbri LM, Hendrick DJ, Diem JE. Effect of atropine on the bronchial response of asthmatic subjects to the inhalation of ultrasonically nebulized distilled water. $J$ Allergy Clin Immunol 1983; 71: 468-472.

252. Eschenbacher WL, Bethel RA, Boushey HA, Sheppard D. Morphine sulfate inhibits bronchoconstriction in subjects with mild asthma whose responses are inhibited by atropine. Am Rev Respir Dis 1984; 130: 363-367.

253. Fujimura M, Amemiya T, Myou S, et al. Role of tachykinins in distilled water-induced bronchoconstriction in guinea-pigs. Clin Exp Allergy 1998; 28: 893-900.

254. del Bufalo C, Fasano L, Patalano F, Gunella G. Inhibition of fog-induced bronchoconstriction by nedocromil sodium and SCG in intrinsic asthma: a double-blind, placebocontrolled study. Respiration 1989; 55: 181-185.

255. Siffredi M, Mastropasqua B, Pelucchi A, Chiesa M, Marazzini L, Foresi A. Effect of inhaled furosemide and cromolyn on bronchoconstriction induced by ultrasonically nebulized distilled water in asthmatic subjects. Ann Allergy Asthma Immunol 1997; 78: 238-243.

256. Robuschi M, Vaghi A, Simone P, Bianco S. Prevention of fog-induced bronchospasm by nedocromil sodium. Clin Allergy 1987; 17: 69-74.

257. Fiocchi A, Riva E, Santini I, Bernardo L, Sala M, Mirri GP. Effect of nedocromil sodium on bronchial hyperreactivity in children with nonatopic asthma. Ann Allergy Asthma Immunol 1997; 79: 503-506.

258. Groot CAR, Lammers JWJ, Molema J, Festen J, van Herwaarden CLA. Effect of inhaled beclomethasone and nedocromil sodium on bronchial hyperresponsiveness to histamine and distilled water. Eur Respir J 1992; 5: 10751082.

259. Robuschi M, Gambaro G, Spagnotto S, Vaghi A, Bianco $\mathrm{S}$. Inhaled frusemide is highly effective in preventing ultrasonically nebulised water bronchoconstriction. Pulm Pharmacol 1989; 1: 187-191.

260. Bootsma GP, Dekhuijzen PN, Festen J, Mulder PG, van Herwaarden CL. Comparison of fluticasone propionate and beclomethasone dipropionate on direct and indirect measurements of bronchial hyperresponsiveness in patients with stable asthma. Thorax 1995; 50: 1044-1050.

261. Herxheimer H. Hyperventilation asthma. Lancet 1948; i: 83-87.

262. Argyros GJ, Roach JM, Hurwitz KM, Eliasson AH, Phillips YY. The refractory period after eucapnic voluntary hyperventilation challenge and its effect on challenge technique. Chest 1995; 108: 419-424.

263. Zeballos RJ, Shturman-Ellstein R, McNally JFJ, Hirsch JE, Souhrada JF. The role of hyperventilation in 
exercise-induced bronchoconstriction. Am Rev Respir Dis 1978; 118: 877-884.

264. Blackie SP, Hilliam C, Village R, Pare PD. The time course of bronchoconstriction in asthmatics during and after isocapnic hyperventilation. Am Rev Respir Dis 1990; 142: 1133-1136.

265. Eschenbacher WL, Sheppard D. Respiratory heat loss is not the sole stimulus for bronchoconstriction induced by isocapnic hyperponea with dry air. Am Rev Respir Dis 1985; 131: 894-901.

266. Smith CM, Anderson SD. A comparison between the airway response to isocapnic hyperventilation and hypertonic saline in subjects with asthma. Eur Respir J 1989; 2: 36-43.

267. Decramer M, Demedts M, van de Woestijne KP. Isocapnic hyperventilation with cold air in healthy nonsmokers, smokers and asthmatic subjects. Bull Eur Physiopathol Respir 1984; 20: 237-243.

268. O'Cain CF, Dowling NB, Slutsky AS, et al. Airway effects of respiratory heat loss in normal subjects. $J$ Appl Physiol 1980; 49: 875-880.

269. Heaton RW, Henderson AF, Gray BJ, Costello JF. The bronchial response to cold air challenge: evidence for different mechanisms in normal and asthmatic subjects. Thorax 1983; 38: 506-511.

270. Tal A, Pasterkamp H, Serrette C, Leahy F, Chernick V. Response to cold air hyperventilation in normal and in asthmatic children. J Pediatr 1984; 104: 516-521.

271. Wilson NM, Barnes PJ, Vickers H, Silverman M. Hyperventilation-induced asthma: evidence for two mechanisms. Thorax 1982; 37: 657-662.

272. Bar-Yishay E, Ben-Dov I, Godfrey S. Refractory period after hyperventilation-induced asthma. Am Rev Respir Dis 1983; 127: 572-574.

273. Rosenthal RR, Laube BL, Hood DB, Norman PS. Analysis of refractory period after exercise and eucapnic voluntary hyperventilation challenge. Am Rev Respir Dis 1990; 141: 368-372.

274. Badier M, Beaumont D, Orehek J. Attenuation of hyperventilation-induced bronchospasm by terfenadine: a new antihistamine. J Allergy Clin Immunol 1988; 81: 437-440.

275. Finnerty JP, Harvey A, Holgate ST. The relative contributions of histamine and prostanoids to bronchoconstriction provoked by isocapnic hyperventilation in asthma. Eur Respir J 1992; 5: 323-330.

276. Ishii Y, Kitamura S. Hyperventilation stimulates the release of prostaglandin I2 and E2 from lung in humans. Prostaglandins 1990; 39: 685-691.

277. Wilkens JH, Wilkens H, Uffmann J, Bovers J, Fabel H, Frolich JC. Effects of a PAF-antagonist (BN 52063) on bronchoconstriction and platelet activation during exercise induced asthma. Br J Clin Pharmacol 1990; 29: 8591.

278. Israel E, Dermarkarian R, Rosenberg M, et al. The effects of a 5-lipoxygenase inhibitor on asthma induced by cold, dry air. $N$ Engl J Med 1990; 323: 1740-1744.

279. Fischer AR, McFadden CA, Frantz R, et al. Effect of chronic 5-lipoxygenase inhibition on airway hyperresponsiveness in asthmatic subjects. Am J Respir Crit Care Med 1995; 152: 1203-1207.

280. Fischer AR, Rosenberg MA, Roth M, Loper M, Jungerwirth S, Israel E. Effect of a novel 5-lipoxygenase activating protein inhibitor, BAYx 1005, on asthma induced by cold dry air. Thorax 1997; 52: 1074-1077.
281. Sheppard D, Epstein J, Holtzman MJ, Nadel JA, Boushey HA. Dose-dependent inhibition of cold-air-induced bronchoconstriction by atropine. J Appl Physiol 1982; 53: $169-174$.

282. Wilson N, Dixon C, Silverman M. Bronchial responsiveness to hyperventilation in children with asthma: inhibition with ipratropium bromide. Thorax 1984; 39: 588-593.

283. Myers JD, Bigby BG, Calvayrac P, Sheppard D, Boushey HA. Interaction of cromolyn and a muscarinic antagonist in inhibiting bronchial reactivity to sulfur dioxide and to eucapnic hyperponea alone. Am Rev Respir Dis 1986; 133: $1154-1158$.

284. Solway J, Kao BM, Jordan JE, et al. Tachykinin receptor antagonists inhibit hyperpnea-induced bronchoconstriction in guinea-pigs. J Clin Invest 1993; 92: 315-323.

285. Latimer KM, O'Byrne PM, Morris MM, Roberts R, Hargreave FE. Bronchoconstriction stimulated by airway cooling. Better protection with combined inhalation of terbutaline sulphate and cromolyn sodium than with either alone. Am Rev Respir Dis 1983; 128: 440-443.

286. del Bono L, Dente FL, Patalano F, del Bono N. Protective effect of nedocromil sodium and SCG on bronchospasm induced by cold air. Eur J Respir Dis 1986; 69 (Suppl 147): 268-270.

287. Juniper EF, Kline PA, Morris MM, Hargreave FE. Airway constriction by isocapnic hyperventilation of cold, dry air: comparison of magnitude and duration of protection by nedocromil sodium and SCG. Clin Allergy 1987; 17: 523-528.

288. Grubbe RE, Hopp R, Dave NK, Brennan B, Bewtra A, Townley R. Effect of inhaled furosemide on the bronchial response to methacholine and cold-air hyperventilation challenges. J Allergy Clin Immunol 1990; 85: 881-884.

289. Rodwell LT, Anderson SD, du TJ, Seale JP. Different effects of inhaled amiloride and frusemide on airway responsiveness to dry air challenge in asthmatic subjects. Eur Respir J 1993; 6: 855-861.

290. Seidenberg J, Dehning J, von der Hardt H. Inhaled frusemide against cold air induced bronchoconstriction in asthmatic children. Arch Dis Child 1992; 67: 214-217.

291. Pennings HJ, Wouters EF. Effect of inhaled beclomethasone dipropionate on isocapnic hyperventilation with cold air in asthmatics, measured with forced oscillation technique. Eur Respir J 1997; 10: 665-671.

292. Brusasco V, Crimi E, Pellegrino R. Airway hyperresponsiveness in asthma: not just a matter of airway inflammation. Thorax 1998; 53: 992-998.

293. Tarodo de la Fuente P, Romagnoli M, Bousquet J, Chanez P. Safety of inducing sputum in patients with asthma of varying severity. Am J Respir Crit Care Med 1998; 157: 1127-1130.

294. Saetta M, Di Stefano A, Turato G, et al. Fatal asthma attack during an inhalation challenge with ultrasonically nebulized distilled water. J Allergy Clin Immunol 1995; 95: $1285-1287$.

295. Aalbers R, Kauffman HF, Koeter GH, Postma DS, de Vries K, de Monchy JG. Dissimilarity in methacholine and adenosine $5^{\prime}$-monophosphate responsiveness 3 and $24 \mathrm{~h}$ after allergen challenge. Am Rev Respir Dis 1991; 144: 352-357.

296. Polosa R, Renaud L, Cacciola R, Prosperini G, Crimi N, Djukanovic R. Sputum eosinophilia is more closely associated with airway responsiveness to bradykinin than methacholine in asthma. Eur Respir J 1998; 12: 551-556. 